\title{
"ERASMO BRASÍLICO":
}

\section{A apropriação do humanismo erasmiano pela catequese jesuítica na América portuguesa (1549-1563)}

"Erasmo Brasílico": The Appropriation of Erasmian Humanism by Rui Luis

\section{RODRIGUES}

Universidade Estadual de Campinas - IFCH/UNICAMP ruiluis@unicamp.br Jesuit Catechesis in Portuguese America (1549-1563)

\section{RESUMO}

Este artigo pretende investigar a presença, nas cartas jesuíticas produzidas na América portuguesa entre 1549 e 1563, de uma das ênfases centrais do humanismo erasmiano: a preocupação catequética. A importância atribuída por esse humanismo à instrução na fé cristã teria criado condições propícias à apropriação, pelos jesuítas, desse ideário. A partir do exame do corpus documental, o artigo questiona duas afirmações geralmente feitas acerca da missionação jesuítica nos primeiros anos de sua implantação na América portuguesa: sua dependência de ideários milenaristas e sua valorização de outros aportes sacramentais, como os batismos "em massa" e o sacramento da confissão, em detrimento da catequese. $O$ objetivo final é indicar como, por meio da apropriação de um aspecto central do humanismo erasmiano, a missionação jesuítica inscreveu a América portuguesa da segunda metade do Quinhentos no universo das preocupações eruditas então cultivadas na Europa.

Palavras-chave: Humanismo erasmiano; Catequese jesuítica; Missionação na América portuguesa.

\begin{abstract}
This article aims to investigate, in Jesuit letters written in Portuguese America between 1549 and 1563, the presence of one main preoccupation of Erasmian humanism: the catechetical emphasis. The importance which that humanism gave to instruction in Christian faith would have created conditions to the appropriation, by the Jesuits, of these ideas. By the analysis of our documental corpus, the article questions two statements generally made about Jesuit missions in the first years of its implantation in Portuguese America: its subjection to Millenarian ideas and its preference for other sacramental contributions, like mass baptism and auricular confession, instead of catechesis. The final aim is to indicate how, by the appropriation of a core aspect of Erasmian humanism, the Jesuit mission inscribed the Portuguese America of sixteenth-century second half in the universe of Humanist concerns then cultivated in Europe.
\end{abstract}

Keywords: Erasmian humanism; Jesuit catechesis; Missionary work in Portuguese America. 


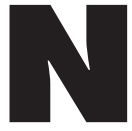

as poucas décadas que medeiam entre o início efetivo da colonização e o final desse tumultuado século XVI, não teria havido, em terras brasílicas, tempo e condições suficientes para a circulação de ideias humanistas e para a articulação de um contexto favorável à difusão desses ideários. Essa seria a conclusão inescapável de quem se dedicasse a investigar tal tema, mormente se dispusesse, para a aferição desse ambiente intelectual, apenas dos instrumentos mais comumente utilizados: existência (ou não) de bibliotecas para cá transportadas, inexistência efetiva de imprensa, falta de lugar, de condições e mesmo de interlocutores para o debate intelectual. Sob todos os aspectos, a América portuguesa encontrava-se, nesse período, nas condições mais adversas para uma participação mínima nas discussões humanísticas que, já por dois séculos, animavam os principais centros de erudição da Europa (VILLALTA, 1997, p. 360-368, esp. p. 360-361; MACHADO, 1972, p. 89-95, esp. p. 93-95).

Essa situação de aparente aridez intelectual não se deveu, no início, aos freios impostos pela política colonizadora, mas às circunstâncias específicas e aos ditames de uma empresa que se ia organizando de forma dinâmica. Não se tratava tanto, inicialmente, de instaurar um controle intelectual com vistas à "obediência"; ao longo da segunda metade do século XVI, diante dos vários desafios que se apresentavam aos portugueses no âmbito das conquistas atlânticas, não havia espaço para uma dedicação aos ócios que a erudição exigia. ${ }^{1}$

Por outro lado, nosso tema exige que se considere também outro aspecto. Enquanto elementos enraizados na cultura europeia, os hábitos intelectuais não dependiam apenas de condições externas - dessas que podem, eventualmente, sofrer o cerceamento das autoridades e padecer as dificuldades próprias de uma temporada adversa. Indicadores da penetração de uma determinada cultura letrada não são apenas a posse de livros e de bibliotecas, mas também o suspiro que nota a ausência desses recursos, ou o pedido expresso por eles numa correspondência, ou ainda, mais significativamente, a difusão, por outros caminhos, de temas e tópicas que, na Europa, encontravam espaço nas formulações eruditas. A aspereza da vida na colônia não significava, portanto, a ausência de fermentos intelectuais, visto que os europeus para cá vindos traziam-nos dentro de si e acabavam por expressá-los.

O objetivo principal deste artigo é expor os resultados de uma investigação sobre a presença de elementos significativos de uma das expressões do humanismo europeu do Quinhentos - o humanismo erasmiano - no contexto da vida intelectual da colônia brasílica durante os anos iniciais da missionação jesuítica aqui realizada. Temos em vista, mais especificamente, o período que vai do início do trabalho dos jesuítas na América portuguesa, em 1549, até 1563; nosso principal corpus documental constitui-se, efetivamente, 
das cartas jesuíticas produzidas aqui nesse período e editadas pelo padre Serafim Leite (1954-1958). Cabe, de início, esclarecer as escolhas - metodológica e de objeto - que foram realizadas.

A missionação jesuítica foi escolhida como índice revelador da presença e da difusão, no contexto da América portuguesa da segunda metade do século XVI, de ideários humanistas largamente discutidos na Europa de então, pela razão bastante evidente de que é na atividade desses religiosos que encontraremos as principais (para não dizer únicas) preocupações de natureza intelectual expressas nesse contexto. O termo "intelectual" serve, aqui, para delimitar essa esfera de atividades e interesses que, distinta da exploração meramente manual e mecânica das riquezas, tomava como base e modelo a cultura erudita europeia de inícios da época moderna: uma cultura assinalada pelas heranças da Antiguidade, mas marcada também pelas formulações distintivamente cristãs. No sentido dessa definição, seriam interesses intelectuais, portanto, não apenas a produção de uma gramática de língua tupinambá (como aquela preparada pelo padre José de Anchieta, em 1595), mas também a articulação de um projeto catequético-missionário: em ambos os casos, as realizações conformavam-se a esse código, erudito e livresco, que constituía o cerne da cultura letrada europeia.

Mas a escolha pela missionação obedece, também, a outra razão de importância. Já analisada em todos os ângulos possíveis, a missionação jesuítica foi muitas vezes atrelada, no passado, às disposições do catolicismo tridentino: esse novo catolicismo que, emergindo da confessionalização católica definida no concílio de Trento, caracterizou-se pela preocupação catequética e pela instauração de mecanismos de controle, em especial a confissão auricular. Estudos mais recentes, por outro lado, têm mostrado que, no caso dos territórios portugueses na América, essa presença evangelizadora teria provocado a emergência de um "diálogo catequético-ritual" no qual os sacramentos - batismo e confissão auricular antes de quaisquer outros - teriam desempenhado um papel fundamental com vistas às dinâmicas de "tradução" da religiosidade europeia para a realidade indígena. ${ }^{2}$

Essa perspectiva trouxe-nos compreensões luminosas sobre o papel desempenhado pelos jesuítas nesses contatos interculturais que, significativamente, tanto alteraram a maneira de pensar dos europeus sobre si mesmos e sobre o resto do mundo. Uma maior atenção ao contexto complexo do período - a divisão da cristandade ocidental desde a década de 1520, a partir do protesto luterano; o impacto provocado pelos contatos com uma humanidade até então desconhecida dos europeus, com a consequente pressão por inserir essa humanidade no desenho soteriológico e escatológico da fé cristã; o enrijecimento, cada vez mais perceptível, dos ambientes intelectuais a partir da década de 1530, com uma nítida mudança de ênfase, da curiositas humanista predominante ainda nas primeiras décadas do século para uma atitude cada vez mais preocupada com a defesa da verdade - levou os pesquisadores a não mais enxergarem na atividade da Companhia de Jesus um mero "instrumento da contrarreforma", dando, assim, peso ao alerta de Marcel 
Bataillon, feito várias décadas atrás e ensejando avanços conceituais importantes em torno do tema, os quais sinalizaram o caráter impreciso da própria noção de "contrarreforma". ${ }^{3}$

Nesse sentido, merece alguns reparos a leitura do movimento jesuítico, implícita na seguinte afirmação de Cristina Pompa (2003, p. 64):

É o objetivo final (humano) de uma conversão voltada para a realização do desenho da plenitude do Ser (divino) que liga [Antônio] Vieira à Contrarreforma e ao projeto jesuítico global expresso nos Exercícios espirituais de Loyola, e que faz com que a Companhia, apesar de criada antes do Concílio, já nasça imbuída do espírito reformador.

Esse trecho sinaliza relativa homogeneização do conceito de reforma católica, tomando esta pela sua configuração pós-tridentina e entendendo-a como uma realidade estanque, o "contrarreformismo militante" (POMPA, 2003, p. 63) que teria caracterizado indistintamente tanto o padre Antônio Vieira quanto os primórdios da Companhia. O resultado é uma perspectiva anacrônica sobre a Companhia, na qual ela aparece, ao fim e ao cabo, como "tridentina antes de Trento".

O fenômeno histórico é, em geral, mais complexo e nele o novo e o antigo, as rupturas e as continuidades, costumam misturar-se. Marcel Bataillon esforçou-se por demonstrar que a Companhia de Jesus possuía raízes que mergulhavam, profundamente, no ambiente do cristianismo do século XV e dos primeiros anos do século XVI, um ambiente que se caracterizou, em especial, por anseios de reforma na religião. Esse mesmo ambiente, como se sabe, moldou ênfases e expectativas daquela vertente do humanismo retórico que, ao ideal de recuperação filológica da Antiguidade, compartilhado por todos os humanistas, unia também uma preocupação especial por produzir uma síntese entre Antiguidade e fé cristã: dessa vertente o humanismo erasmiano se constituiu no exemplo mais acabado. Assim, não é fortuito que Bataillon tenha enxergado, nos primórdios da Companhia de Jesus, a presença de um aporte erasmiano: o Enchiridion Militis Christiani, obra erasmiana extensamente divulgada após sua edição por Froben, em 1518, e que Inácio teria lido. Evidência que a própria memorialística e hagiografia dos jesuítas procuraria, posteriormente, encobrir (BATAILLON, 1983). ${ }^{4}$

Coloca-se, portanto, a necessidade de se sondar, de forma menos homogeneizante e estereotipada, as configurações que a missão jesuítica pode ter apresentado no período e no ambiente que nos interessam mais diretamente, bem como de compreender as relações que ela pode ter mantido com essa forma específica de humanismo. Desnecessário dizer que nosso interesse pelo humanismo erasmiano não significa, de forma alguma, qualquer preocupação em majorar o papel desempenhado por Erasmo de Rotterdam; trata-se, antes, de compreender que esse humanismo, e aquele que sem qualquer dúvida foi seu principal representante, inseriam-se numa tradição mais ampla da qual se abeberaram. Por outro lado, não se pretende compreender a dinâmica pela qual os jesuítas entraram em contato com essa tradição pela noção, já tão desgastada, de "influência". Os jesuítas não 
foram "influenciados" por Erasmo, nem aceitaram em bloco e acriticamente as ênfases e características do humanismo erasmiano; ao contrário, apropriaram-se de aspectos desse humanismo que thes pareceram pertinentes e, a partir desse esforço criativo de leitura, colaboraram para disseminar itens desse ideário - não sem, previamente, modificá-los onde julgaram oportuno. ${ }^{5}$

Nossa hipótese, portanto, é a de que as cartas jesuíticas produzidas na América portuguesa nos primeiros instantes da missionação aqui desenvolvida podem sinalizar, de maneira bastante eficaz, a presença (e consequentemente a difusão) de um ideário humanista que alcançava então, na Europa, altíssima penetração. A edição do padre Serafim Leite, realizada para as Monumenta Historica Societatis lesu e aqui publicada por ocasião das comemorações do IV Centenário da cidade de São Paulo, foi escolhida não apenas em vista da comodidade do acesso às fontes e pelo excelente trabalho crítico com os documentos; de fato, a edição, compreendendo as cartas escritas entre 1549 e 1563, cobre um periodo que nos parece estratégico. ${ }^{6}$

Partimos da premissa de que essa presença do humanismo erasmiano seria mais perceptível nesse primeiro período da missionação jesuítica (antes de 1556, ano da redação do Diálogo de Nóbrega que teria sido emblemático das mudanças experimentadas nos métodos de evangelização). Ao mesmo tempo, as cartas escritas entre 1556 e 1563 permitiriam avaliar se de fato ocorreram mudanças, de que qualidade teriam sido e se afetaram realmente as práticas evangelizadoras. Afinal, se ocorreram mudanças, o que passou a ser enfatizado posteriormente pode lançar luz sobre a maneira como o trabalho era desenvolvido antes da viragem. ${ }^{7} \mathrm{O}$ ano de 1563 é também emblemático por ter sido o ano em que se concluiu o concílio de Trento; nesse sentido, e considerando-se que as disposições conciliares precisaram de tempo para sua difusão e efetiva implementação, as dinâmicas da missionação jesuítica evidenciadas pela documentação escolhida não poderiam ser reduzidas a uma efetivação instrumental da "política" tridentina; precisam ser compreendidas em si mesmas e a partir das relações que constituíram com as tradições que deram forma a elas. ${ }^{8}$

Precisamente em virtude dessa especificidade da segunda metade do século XVI, em que a reforma empírica do catolicismo, que culminou em Trento, precisou lidar com as tensões provenientes da divisão da cristandade e de uma preocupação cada vez maior com a ortodoxia doutrinária, é que decorrem algumas das dificuldades que o tema proposto enfrenta e que são levantadas pelas próprias fontes escolhidas. Passou a existir no âmbito da Companhia de Jesus, a partir de determinado momento, um silêncio em relação a Erasmo, do qual dão testemunho as próprias deformações hagiográficas perpetradas na imagem de seu fundador pela memorialística oficial jesuítica mais antiga e apontadas por Marcel Bataillon (1983). ${ }^{9}$ Se somarmos essa tendência a excluir sinais da presença erasmiana ao fato de que as cartas jesuíticas sofriam intenso processo editorial antes de uma divulgação mais ampla, concordaremos com a observação de José Eisenberg, para quem o próprio silêncio nesses documentos é revelador: "Mesmo silêncios e omissões nas cartas contam 
algo a respeito da atividade jesuítica, aquilo que não deveria ser dito ou que precisava ser ocultado" (EISENBERG, 2000, p. 49).

É preciso, portanto, matizar o silêncio documental, procurar inquirir pelo seu significado. Nossa alternativa de análise deve, assim, se constituir na proposta de uma leitura "a contrapelo". De seu lado, os procedimentos editoriais aplicados às cartas pela própria Companhia representam um desafio que pode ser superado por meio do exame crítico. $O$ próprio Eisenberg admite que "as práticas institucionais eram controladas apenas até um certo ponto, pois um controle burocrático estrito das atividades acabaria por cercear o desenvolvimento da instituição" (EISENBERG, 2000, P. 49).

Einsenberg (2000, p. 49) nos recorda que a "instituição epistolar era a espinha dorsal da empresa missionária jesuítica no século XVI"; uma instituição que obedecia a regras claras e bem definidas, tanto em termos práticos (o que deveria ser escrito nas cartas "edificantes", aquelas destinadas à divulgação mais ampla, e o que deveria ser escrito nas "hijuelas", documentos internos que relatavam mais diretamente as dificuldades da empresa missionária) como em termos retóricos (as cartas edificantes seguiam, em geral, os preceitos da ars dictaminis medieval, a escrita mais formal; enquanto as "hijuelas" adotavam o tom menos formal da escrita clássica, caracterizada pela intimidade, privacidade e brevidade).10

Nas cartas edificantes, e justamente para que pudessem "edificar", os sucessos da missionação eram valorizados, mas também as dificuldades enfrentadas pelos missionários se prestavam a cumprir um papel retórico importante:

\begin{abstract}
Nas cartas do século XVI, a ratificação da unidade da Companhia de Jesus se realiza principalmente por meio de enunciados que, recuperando textos hagiográficos, como a Legenda aurea, de Voragine, confirmam a caridade e a fé da ação do missivista, dando testemunho do seu absoluto despojamento e obediência. A tradução e a edição das cartas para edificar também o público leigo da Europa acompanhavam-se da sua remessa para todas as conquistas (Hansen, 2003, p. 32).
\end{abstract}

Mesmo os eventuais fracassos, na ótica cristã, se prestavam assim a encômios edificantes. A veiculação de informações acontece nas cartas, portanto, por meio dos filtros próprios da difusão: quem lia a carta determinava, em grande medida, o que deveria ser dito, e de que forma.$$
- \text { II - }
$$

A relação entre o humanismo erasmiano e a catequese jesuítica é daquelas que não parecem claras à primeira vista. Cumpre, portanto, começarmos nosso percurso inquirindo pela preocupação que o humanismo erasmiano devotou a essa atividade específica, a instrução nos assuntos da fé cristã.

Para Adone Agnolin (2007, p. 50), o papel fundamental desempenhado pelos catecismos, a partir da segunda metade do século XVI, teria se ligado, inequivocamente, à vitó- 
ria de uma determinada postura de valorização do conteúdo doutrinário, emblematizada de início pelos Catecismos luteranos, sobre uma proposta de teor mais humanista, cujo símbolo teria sido o "manual" erasmiano para a vida cristã, representado pelo Enchiridion Militis Christiani. Alhures, procuramos demonstrar como, por mais correta que esteja a percepção feita por Agnolin, da centralidade da pietas para Erasmo, e por mais verídico que seja atribuir aos Catecismos luteranos um lugar precípuo nas novas formas de se encarar a religião que se estabeleceriam a partir da década de 1530, a oposição realizada por Agnolin encobre uma complexidade muito maior do cenário sob consideração e, em especial, uma complexidade muito maior no interior do próprio humanismo erasmiano. De fato, os desdobramentos confessionais, com sua ênfase na transmissão e aprendizado de conhecimentos religiosos (o âmbito da catequese) que exigiam, previamente, um esforço maior no sentido da clareza e da delimitação confessional (o âmbito da formulação doutrinária), foram também devedores, em grande medida, de impulsos oriundos do próprio humanismo erasmiano; falou-se da vitória dos catecismos como derrota da proposta erasmiana, quando se deveria falar dessa vitória como consequência final dessa proposta, ainda que uma consequência não desejada e totalmente imprevista. ${ }^{11}$

No Enchiridion erasmiano, assim como em diversas outras obras do humanista, o ideal de pietas christiana não foi construído à parte da valorização do conteúdo doutrinário; ao contrário, a compreensão das doutrinas cristãs aparece como elemento fundamental para a profissão de fé do cristão, constituindo-se em ingrediente indispensável para uma vida piedosa. Na "Epístola ao piedoso leitor" com que abriu, em 1522, a edição de sua paráfrase ao Evangelho de Mateus, Erasmo escreveu: "Agora há muitos quinquagenários que desconhecem os votos que fizeram no batismo, que nem imaginam, de fato, o que significam os artigos da fé, a oração do Senhor, os sacramentos da Igreja"12 (ERASMO, 1544, p. 20). Para remediar isso o humanista propunha uma instrução pós-batismal mais cuidadosa e que, talvez, pudesse incluir um ato de compromisso. Posteriormente, supôs-se que a sugestão indicava menosprezo, por parte de Erasmo, dos sacramentos do batismo e da confirmação; houve quem pretendesse ver nela um apoio para o radicalismo anabatista (FRIESEN, 1998). ${ }^{13}$ O fato é que, em termos globais, a proposta feita no prefácio não nos permite tais conclusões; no que Erasmo escreve não se menospreza o batismo nem se coloca em discussão o crisma, com a validade do sacramento ministrado na infância permanecendo o tempo todo implícita. Longe de colocar em dúvida os sacramentos, o que Erasmo pretendia era assinalar uma deficiência existente no cristianismo de seus dias: as pessoas frequentavam a missa, recebiam os sacramentos, mas desconheciam o que tudo isso significava.

Deve-se notar que a proposta erasmiana de uma instrução pós-batismal mais acurada respondia às condições específicas da cristandade latina, nas quais a tradição já longamente consolidada do batismo de infantes conjugava-se a uma catequese que, para Erasmo e para muitos de seus contemporâneos, era apenas sofrivel (Rodrigues, 2012, p. 350; Delumeau, 1981). Por outro lado, o contexto em que se realizaria a missionação, mormente nos territórios extraeuropeus, fornecia uma oportunidade ímpar para a prática de uma ca- 
tequese cuidadosa, prévia ao batismo. Erasmo não se ocupou dessa questão; sabe-se que seu interesse pelo "Novo Mundo" foi bastante reduzido e que os "novos territórios" receberam dele poucas menções. ${ }^{14}$ No entanto, parece aceitável observar que essa preocupação erasmiana com a instrução encontraria receptividade entre os jesuítas.

Antes de expormos as evidências nesse sentido, que a documentação compulsada nos permitiu coligir, é importante acrescentar que o locus dessa preocupação erasmiana com a catequese era, prioritariamente, a pregação. Novamente, estamos diante de uma proposta que leva em conta o contexto das práticas eclesiais da velha Europa, no qual Erasmo encontrava-se inserido. Um exemplo emblemático dessa percepção da pregação como o lugar mais efetivo para uma contínua instrução dos fiéis aparece numa das últimas obras escritas por Erasmo: o Ecclesiastae siue De ratione concionandi libri quatuor ("Os pregadores ou quatro livros sobre o método pelo qual se deve pregar"), um tratado sobre a pregação que Froben publicou em 1535.

Discutindo nesse texto as funções do sacerdote, Erasmo afirma:

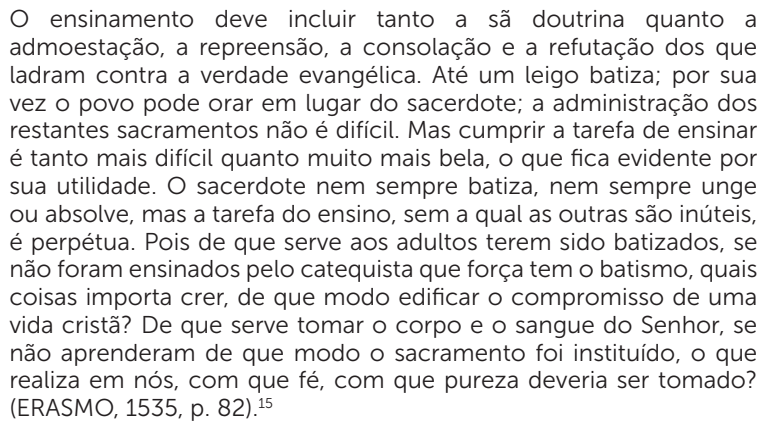

A preocupação de base, como fica evidente, é com a falta de compreensão das realidades envolvidas na participação dos sacramentos e de como essas realidades cooperam na edificação do "compromisso de uma vida cristã" ("professionem Christianam uitam", expressão emblemática, porque sinaliza elemento característico da perspectiva erasmiana: a importância da correspondência entre fé e vida). Não devemos ignorar a dimensão retórica na qual Erasmo se move: suas ênfases ("de que serve aos adultos terem sido batizados [...]?"; "de que serve tomar o corpo e o sangue do Senhor [...]?") não têm como objetivo desprestigiar os sacramentos, ou questionar sua validade em face de uma catequese deficiente, mas sublinhar os benefícios que uma instrução adequada traria àquele que recebe os sacramentos e já é beneficiado por eles (Rodrigues, 2012, p. 324-328).

Uma leitura do Ecclesiastae nos permite discernir bem a importância que Erasmo atribuía ao ato da pregação enquanto ferramenta de instrução religiosa. Trata-se não apenas do maior dos textos isolados que Erasmo produziu, como também da obra que, certamente, Ihe consumiu mais tempo e esforços, num processo de escrita que se desenvolveu ao 
longo de doze anos. É fato que, no Ecclesiastae, a fluência literária do humanista parece prejudicada pela necessidade rígida de detalhar ao máximo seu tema. O que falta ao texto em termos de verve (tão abundante nos outros escritos de Erasmo), sobra-lhe, contudo, em clareza. Nesse escrito, Erasmo ocupou-se da formação completa do pregador: o Livro I contrasta a situação da pregação nos dias de Erasmo com seus modelos elevadíssimos, exemplificados pela roupa sacerdotal de Aarão (Erasmo, 1535, p. 1-104); os Livros II e III examinam detalhadamente a concepção e a entrega do sermão sob o ponto de vista da retórica (Erasmo, 1535, p. 109-404); já o Livro IV, finalmente, trabalha com diversos tópicos teológicos (como o caráter trinitário da deidade, a lei de Deus e suas configurações ao longo da história da salvação, a novidade do evangelho, as virtudes teologais, as diversas expressões da piedade - a Deus, à terra natal, aos pais etc.), numa tentativa de formular resumos bastante úteis para o pregador e cuja aplicabilidade no trabalho catequético é facilmente perceptível. De fato, o tempo todo Erasmo considerou o pregador como um catequista que, executando um papel bem demarcado no âmbito da celebração litúrgica, devia aproveitar ao máximo a oportunidade de que dispunha para realizar seu trabalho de mestre.

Dificilmente os jesuítas ficariam insensiveis a uma tal valorização da pregação. John O'Malley (2004, p. 405-411) discute as várias razões pelas quais era preciso cercar de reservas o nome de Erasmo, como forma de proteger a própria Companhia; mas isso não impediu que vários colégios jesuíticos possuíssem coleções das obras de Erasmo e que um jesuíta de alto escalão como Salmerón (escolhido juntamente com Diego Laínez pelo próprio Inácio, a pedido do papa Paulo III, para atuar como teólogo junto ao concílio) tivesse estudado atentamente as Paráfrases de Erasmo aos Evangelhos e o Ecclesiastae. ${ }^{16}$ Essas evidências provavelmente apontam para um universo mais amplo; tendo em vista a enorme difusão das formulações erasmianas (uma difusão que, ao fim e ao cabo, dificultou o trabalho da própria censura; no que diz respeito às obras erasmianas, o Índice promulgado por Pio IV em 1564 já era bastante moderado, em comparação com o de seu predecessor Paulo IV), podemos supor que o apreço erasmiano pela pregação tenha encontrado eco nas aspirações dos missionários jesuítas e tenha ajudado a animar seus esforços nesse campo. ${ }^{17}$

Parece-nos claro, portanto, que a missionação jesuítica poderia representar um locus adequado para a difusão de um ideário humanista bastante presente ao longo do século $\mathrm{XVI}$, aquele do humanismo erasmiano; e um ideário que, como tentamos indicar, tinha na preocupação com a instrução religiosa dos fiéis, com a catequese realizada em especial pela pregação, uma de suas características mais decisivas. Todavia, antes de passarmos ao exame de algumas instâncias documentais importantes, presentes nas cartas jesuíticas, há outra questão bastante levantada pela historiografia em torno da Companhia de Jesus que precisa ser reposicionada: a relação dos jesuítas com posturas apocalípticas, como aquelas evidenciadas pelos primeiros missionários franciscanos a missionarem na Nova Espanha. 


\title{
- III -
}

Em seu trabalho Religião como Tradução, Cristina Pompa (2003) procura identificar os "anseios milenaristas" como um dos principais motores do avanço jesuítico nas primeiras décadas de trabalho missionário. Segundo a autora, esse aspecto milenarista teria convivido com a ênfase catequética ao longo do século XVI; a transição para um modelo exclusivamente catequético teria se dado com a publicação do De temporibus novissimis, de José de Acosta (1590), uma crítica das expectativas milenaristas de fundo joaquimita. A nova postura estaria mais de acordo com o espírito do concílio de Trento, que,

[...] respondendo com a sistematização da ortodoxia aos medos apocalípticos suscitados por Lutero enquanto Anticristo, elaborou com minúcias o projeto de catequese, interna e externa, e determinou que seu eixo principal não era mais o batismo, mas a confissão. Por isso de nada adiantavam os batismos em massa praticados pelos franciscanos no México, como diz Acosta, "antes que saibam medianamente a doutrina cristã, e sem que conste que estão arrependidos de sua vida criminal e supersticiosa" (Pompa, 2003, p. 61).

O tema do milenarismo cristão é complexo, e seu uso pela autora merece ser relativizado. A partir da inegável importância que o pensamento de Joaquim de Fiore adquiriu em certas vertentes do franciscanismo e da presença de elementos milenaristas em outros contextos da vida europeia dos séculos XV e XVI (como, por exemplo, no próprio Colombo), a autora enxerga uma presença maciça desse viés na preocupação missionária que nasce juntamente com as descobertas:

\begin{abstract}
A bula do papa Paulo III, além de reconhecer-lhes laos indígenas do Novo Mundo] a dignidade de homens, mandava trazer os 'naturais' para a fé cristã pela pregação do Verbo de Deus e do exemplo. A imposição da religião dos conquistadores encontrava assim sua plena legitimação, realizando a grandiosa profecia da Conquista: a construção do Reino de Deus na terra, com um povo virgem. Aqui está um dos nós conceptuais da pregação missionária, nó que, aliás, tinha dirigido teologicamente até a própria 'descoberta': o milenarismo cristão. (Pompa, 2003, p. 46).
\end{abstract}

Não há o que observar às ligações que a autora faz entre o milenarismo joaquimita, o sonho franciscano de construção de uma "nova Igreja" no Novo Mundo e, em Portugal, manifestações como as "trovas do Bandarra", o sebastianismo e a obra escatológica do padre Antônio Viera (Pompa, 2003, p. 47-48); os vínculos são claros. Seu equívoco está em estender essa perspectiva de forma global, tomando-a quase como um posicionamento padrão do catolicismo. Sobretudo, Cristina Pompa (2003, p. 48, grifo nosso) se equivoca, em nossa opinião, ao transpor esse viés de forma indiscriminada para a Companhia de Jesus: "Franciscanos e Jesuítas", escreve ela, "transferiram para o continente sul-americano o pensamento milenarista joaquimita". No entanto, poucas linhas abaixo ela é obrigada a reconhecer, algo contraditoriamente, que nos jesuítas "esse pendor profético é menos evidente, porque a iminência do Apocalipse não condiz com seu projeto catequético de longo prazo" (POMPA, 2003, p. 48, grifo nosso). 
A raiz desse equívoco, a nosso ver, está no fato de que a autora tende a tomar todas as referências de cunho escatológico e relacioná-las com o milenarismo, como se o viés milenarista fosse o único possível na escatologia cristã. Essa tendência transparece claramente nas várias referências que Cristina Pompa faz a uma passagem tida como capital, o Evangelho segundo S. Mateus, 24, 14. Vejamos ao menos uma dessas referências:

No Brasil, percebe-se também um clima milenarista, basta pensar na primeira página da Histoire de la mission, de d'Abbeville, onde o capuchinho transcreve a profecia de Mateus: "Et predicabitur hoc euangelium regni in uniuerso orbe, in testimonium omnibus gentibus, et tunc ueniet consummatio" (Mt 24, 14). Também os outros autores não deixam de mencionar o fim dos tempos e o juízo final, que coincidiria com a pregação da palavra de Deus aos selvagens (POMPA, 2003, p. 48, grifos da autora). ${ }^{18}$

Sem entrar no mérito da análise do milenarismo capuchinho, é preciso destacar que a simples menção aos eventos escatológicos (a consumação ou fim dos tempos, o juízo final e, segundo o texto bíblico, a necessária pregação do evangelho a todos os povos como elemento prévio e condicionante desses eventos) não equivale a milenarismo. Um estudo deste tema poderá mostrar que a perspectiva milenarista surgiu na patrística grega a partir do século II, mas nunca foi predominante; no contexto latino, a posição que predominou foi a de Santo Agostinho, para quem o "milênio" (um período de governo de Cristo na terra que deveria durar mil anos; a imagem é tomada de Apocalipse 20, 1-6) não fazia referência a um intervalo literal de tempo; tratava-se, ao contrário, do reinado que Cristo exerceria, na história, através da Igreja, figurado pela "pedra que se soltou de uma montanha, sem auxílio de mãos" e que "tornou-se uma montanha e encheu a terra toda", de acordo com a profecia de Daniel 2, 34-35 (a relação é feita por todos os intérpretes). Assim, Agostinho foi um dos primeiros a dar ao milênio uma interpretação alegórico-histórica cujo cumprimento equivalia ao estabelecimento da Igreja institucional.

Os adeptos dessa perspectiva não-milenarista, no entanto, continuaram falando em eventos escatológicos como o fim dos tempos e o juízo final enquanto ocorrências que, a seu tempo, deveriam encerrar a história e inaugurar a eternidade. Há que distinguir, portanto, fortemente, entre "escatologia" enquanto parte da Dogmática cristã que trata dos "nouissimi" ou das últimas coisas, e "milenarismo" enquanto uma entre várias posturas escatológicas possíveis. ${ }^{19}$

O mesmo pode se dizer da "visão edênica de Vasconcelos, que coloca o paraíso terrestre no Brasil" e que a autora também relaciona, como parte de uma "história de cunho providencialista", ao milenarismo (POMPA, 2003, p. 48). ${ }^{20}$ A perspectiva edênica faz parte da protologia cristã (a parte da Dogmática que trata dos começos), e o mito da localização ocidental do Éden (um topos antigo, como Sergio Buarque de Holanda nos mostra) não se vincula necessariamente ao milenarismo (Holanda, 2000). "Milenarismo" e "história de cunho providencialista" têm em comum, por sua vez, o necessário pano de fundo religioso, mas há diferenças marcantes: todo cristão no século XVI era, de alguma maneira, 
"providencialista", embora não se valesse de tal formulação; mas não era necessariamente milenarista.

Erasmo nunca defendeu uma postura milenarista. Em sua Paráfrase do evangelho segundo São Mateus, ele dá a entender que o texto de Mt 24, 14, sobretudo em sua forma negativa ("Non enim uenturus est mundi finis prius, quam hoc euangelium regni coelorum, per omnia regna mundi praedicetur, omnesque nationes occuparit" (ERASMO, 1544, p. 289-290), ${ }^{21}$ subentende um processo paulatino de evangelização, a cumprir-se na vigência desse "tempo da Igreja"; o fim não viria precedido do advento de um milênio, devendo esse termo ser compreendido de forma alegórica, com base na formulação agostiniana tradicional.

Não seria esta perspectiva mais semelhante à dos jesuítas, para quem, segundo Cristina Pompa (2003, p. 48), "a iminência do Apocalipse não condiz com seu projeto catequético de longo prazo"? Essa pergunta pode ser respondida afirmativamente, ao menos para o período coberto por nossa pesquisa, levando-se em conta as pouquíssimas menções de caráter escatológico nas Cartas escritas na América portuguesa entre 1549 e 1563.

Em 5 de junho de 1552, Nóbrega escreveu aos moradores de Pernambuco uma carta que, por suas características, nos oferece um exemplo da sua retórica sermônica. Nessa carta, há uma interessante referência de cunho escatológico:

Muitas vezes cuido eu, e hé pera mim grande sinal do mundo durar
pouquo, pois Nosso Senhor vejo que quer esperdiçar tanto sua
glória, e busca tantas maneiras pera a dar, e ha dá e promete tão
barata, como cousa que muito já deseja encher ho numero dos
escolhidos, e recolher os chamados e convidados hàs bodas de seu
Filho (NÓBREGA apud LEITE, 1954-1958, v. I, p. 332, grifos nossos). ${ }^{22}$

Nóbrega se refere às indulgências concedidas pelo Jubileu do Ano Santo de 1550, "ho tisouro todo da Santa Igreja, pera pagardes com elle todas vossas dividas" (LEITE, 19541958, v. I, p. 331-332), e vê essa "liberalidade" de Cristo como evidência dos desejos divinos no sentido da consumação final; a linguagem do jesuíta embute não apenas a Mateus 24, 14 mas, também, a outras passagens de natureza escatológica. Todavia, é digno de nota que essas menções se fazem de forma bastante discreta; por outro lado, nada em sua formulação teológica obriga-nos a pensar numa perspectiva milenarista. O sentimento de iminência com relação à "consumação dos séculos", como já procuramos deixar claro, é subjacente à escatologia cristã como um todo.

Mais significativamente, é preciso destacar que essa menção discreta, feita durante o terceiro ano da missionação em terras brasílicas, é a primeira que surge nos documentos jesuíticos estudados em nossa pesquisa. Pouco, sem dúvida, se o objetivo fosse caracterizar os jesuítas como arautos de uma expectativa de cunho joaquimita.

Outra referência, na mesma carta, poderia ser lida numa ótica joaquimita apenas se forçarmos a evidência textual sem levar em conta seu contexto. Escreve Nóbrega: "Queira 
o Senhor, por quem hé, aceitar meus desejos, os quais são fazer-vos Nosso Senhor tais quais erão hos da primitiva Igreja; porque, se haí não houver grande fogo de charidade, como será possivel ence[n]deren-se os corações do Gentio?" (Leite, 1954-1958, v. I, p. 333). Aqui, Nóbrega trabalha sermonicamente com a ideia dessa superioridade exemplar da Igreja primitiva, que teria sido perdida com o embotamento da caridade; trata-se de outra tópica abundante no cristianismo desde os Pais da Igreja. No entanto, se é verdade que a perspectiva joaquimita se serve dessa percepção para pregar o advento de um período áureo no futuro, no qual "tudo voltaria a ser como antes", é verdade também que a mera utilização do topos não significa identificação com a lógica milenarista. O pregador Nóbrega expressa um anseio em relação aos seus leitores e, indiretamente, em relação ao seu objetivo máximo (a evangelização do gentio); e, o que é importante, o faz em linguagem sermônica, um elemento que não pode ser perdido de vista. Por outro lado, essa idealização da Igreja primitiva, que animou diferentes movimentos heterodoxos ao longo do período medieval (Cohn, 1970, p. 37-41; Leff, 2002; Rodrigues, 2012, p. 527-530), já tinha sido incorporada, décadas antes de Nóbrega incluí-la em sua carta, pelo humanismo retórico, no qual ao "retorno aos Antigos", à apropriação da herança da Antiguidade pretendida pela filologia humanista, correspondia um retorno "ad fontes", às fontes da fé (em especial o texto neotestamentário e a teologia patrística), valorizadas justamente em virtude de sua pretensa pureza. Esse anseio encontrava-se, assim, no coração do apelo humanista pelo retorno à "uetus theologia", à teologia feita à moda antiga, em contraste com os teólogos "novos" (ou neoterici) que trabalhavam à maneira dos escolásticos (Rodrigues, 2012, p. 63-100). Finalmente, a tópica fora utilizada largamente, desde a Antiguidade tardia, para justificar a existência monástica enquanto locus onde a pureza e integridade dos dias apostólicos seria recuperada; mais uma vez, sem que o emprego desse topos denunciasse qualquer aspiração milenarista (Markus, 1997, p. 168-169).

Numa correspondência datada de setembro do mesmo ano, o irmão Vicente Rodrigues, dirigindo-se da Bahia aos padres e irmãos de Coimbra num contexto retórico de apelo por missionários (presente, aliás, na maioria das cartas "edificantes"), faz uso da tópica da "nova igreja". Escreve ele:

\begin{abstract}
Ah, Hermanos míos, muchas vezes pienso que esta gentilidad espera que vuestro sangue sea fundamento de la aedificación desta nueva iglesia, portanto traedlo puro, porque para lo conferir con el de Christo mira[d] lo que aveis menester, pues el de Christo sea piedra y verdadero alicerce de nuestra Iglesia! (RODRIGUES apud LEITE, 1954-1958, v. I, p. 413). ${ }^{23}$
\end{abstract}

Aqui o jesuíta se refere à "nova igreja" numa perspectiva franciscana e joaquimita, tendo em vista a restauração no Novo Mundo da igreja primitiva e de sua posição superior? Como observamos, ainda que o autor estivesse a se referir, retoricamente, a uma Igreja renovada segundo o modelo da primitiva cristandade, isso não equivaleria necessariamente a joaquimismo e a milenarismo; as ênfases milenaristas e joaquimitas se apropriaram da ideia de restauração do fervor da igreja primitiva, mas a recíproca não é necessariamente válida. 
Por outro lado, parece que, aqui, o jesuíta está sendo bem mais prosaico. A distinção, feita pelo texto, entre "iglesia" e "Iglesia" sugere que a primeira menção seja uma referência à igreja "particular", ou seja, ao estabelecimento da Igreja numa determinada região; ao passo que a segunda referência aponta para a Igreja universal, a qual é composta pelas muitas igrejas particulares (Tillard, 1999). A "igreja particular" ou "local" (iglesia), normalmente identificada com uma diocese, junta-se às outras igrejas particulares ou locais para formar a Igreja católica (Iglesia). Tratar-se-ia, portanto, da mesma Igreja Católica que, na lógica do autor, careceria ser regada pelo sangue dos irmãos de Coimbra em sua implantação na América, e não de uma "nova" Igreja em qualquer sentido milenarista.

Não há outras referências nas Cartas, entre 1549 e 1563, que possam ser remotamente consideradas como de fundo milenarista. A ênfase, contínua, na evangelização; a preocupação, contínua, em obter trabalhadores para a colheita da messe espiritual; esses elementos estão presentes o tempo todo, seja na forma de indicações breves, diretas e até mais calorosas, seja em construções retóricas mais rebuscadas e que visavam obviamente influenciar os leitores. Mas não se traduzem, até onde pudemos enxergar, em anseios de natureza milenarista ou joaquimita.

Nossa análise, portanto, coloca em dúvida a virada que Cristina Pompa procura ver na prática jesuítica a partir do final do século XVI. Quando Acosta critica os batismos feitos sem instrução adequada, é fora de dúvida que pensa até na prática ingênua desenvolvida pelos primeiros missionários franciscanos na América hispânica, toda ela indubitavelmente influenciada pelas esperanças milenaristas; todavia, a prática jesuítica nunca apresentou o porte daquela desenvolvida no México pelos franciscanos; nem teve origem, em nosso entender, na mesma motivação de fundo milenarista. ${ }^{24}$

Será que a valorização da catequese, no contexto da missionação jesuítica desenvolvida na América portuguesa, ocorreu apenas após o mencionado "desencanto" com a seara que se imaginava tão promissora? É fato que os primeiros anos de pregação jesuítica na América portuguesa foram marcados pelo otimismo, insuflado pelo interesse dos indígenas e na esteira do qual os batismos foram de início mais numerosos; é fato, também, que o desânimo posterior foi motivado pela observação de que os novos convertidos voltavam de forma rápida às suas práticas antigas, ou de fato nunca as haviam abandonado. ${ }^{25}$ No entanto, resta por se provar que, no caso dos jesuítas, esse otimismo inicial tenha significado uma preocupação menor com a catequese, em razão de uma confiança "milenarista" no poder do batismo. Examinaremos isso a seguir.

$$
- \text { IV - }
$$

Não pretendemos nos deter no problema específico dos conteúdos transmitidos pela catequese jesuítica em seus primeiros anos nas terras brasílicas. Foram aqueles padronizados pelo catolicismo; foram as práticas tradicionais da Igreja, inclusive a da importância da confissão que, antes de qualquer valorização recebida posteriormente em Trento, já era 
tida em alta conta pela espiritualidade inaciana (Pompa, 2003, p. 67). O que nos interessa destacar é o fato marcante de que a prática jesuítica se apropriou da ênfase erasmiana no ensino/catequese e fez dela o eixo central de sua atividade missionária.

A leitura das cartas produzidas no Brasil entre 1549 e 1563 não nos ofereceu nenhum sinal de que os primeiros anos de catequese jesuítica tivessem sido marcados por uma ênfase privilegiada no batismo em detrimento da catequese. Ao contrário, são numerosas as referências documentais que mostram a catequese como antecedente indispensável ao batismo (com exceção, obviamente, do batismo in articulo mortis; todavia, mesmo quando havia suspeita de que o enfermo suportaria mais um dia algum tipo abreviado de instrução era ministrado). ${ }^{26}$ Mesmo a confissão, largamente praticada até mesmo por meio de intérprete, não se constituía em eixo central da ação missionária: visto ser sacramento, a confissão subentendia a recepção prévia do batismo. ${ }^{27}$

Vejamos algumas referências:

Començamos a visitar sus aldeas quatro compañeros que somos; y conversar con ellos familiarmente, presentándole el reyno del cielo si hizieren lo que le enseñáremos. Estos son acá nuestros pregones adonde nos hallamos, conbidando a los muchachos a leer y escrivir, y desta manera les enseñamos la doctrina y les predicamos, porque con la misma arte con que el enemigo de la humana generación venció al hombre, con essa misma sea vencido; "Eritis, inquit, sicut dii scientes bonum et malum" (NÓBREGA apud LEITE, 1954-1958, v. I, p. 139, grifos nossos). ${ }^{28}$

Nesta carta há uma curiosa reprodução da perspectiva erasmiana: a referência ao texto latino de Gênesis 3, 5 permite-nos entender o ensino como maneira de reverter o mal provocado pela tentação diabólica, o oferecimento ao homem da "árvore do conhecimento". Tratando da educação de crianças, Erasmo $(2006$, p. 25-26, 27) afirmara:

Correto, por isso, o que foi escrito por alguém: o primeiro, o segundo e o terceiro passos para se alcançar o ápice de toda felicidade consistem na reta instrução e na autêntica educação. Com tais palavras de incentivo, Demóstenes encarecia a correção na pronúncia. Estava ele coberto de razão, entretanto o ensino adequado concorre em maior intensidade para 0 bem da sabedoria do que a correta pronúncia em relação à eloqüência. Com efeito, a fonte de toda virtude consiste numa educação diligente e aprimorada. De igual modo, em relação à demência e à perversidade, o primeiro, o segundo e o terceiro passos resultam da educação descuidada e corrupta. E pensar que tudo depende, de modo preponderante, de nós mesmos. [...] A natureza é de per si eficiente, no entanto, a educação, com sua eficácia mais avantajada, pode superá-la. ${ }^{29}$

Muito embora devesse enfrentar impedimentos bastante fortes, em especial o dano causado pelo pecado às capacidades humanas, ${ }^{30}$ a educação poderia reverter essa propensão à imitação do mal que, para Erasmo, constituía o cerne do pecado humano (Godin, 1982, p. 193-196; Kohls, 1996, p. 143-158). Efetivamente, tal posicionamento não representava uma idiossincrasia erasmiana; essa perspectiva bastante positiva, marcada pela re- 
lativização dos efeitos do pecado original, correspondia tanto à síntese da tradição latina realizada pelo tomismo quanto à absorção de concepções caras à Patrística grega (Rodrigues, 2012, p. 316-318).

Nesse sentido, é óbvio que a conexão entre instrução e apagamento dos efeitos provocados pela Queda, tal como aparece na carta de Nóbrega acima citada, poderia indicar uma dependência direta da teologia tomista, sem necessidade de mediação do humanismo erasmiano. No entanto, dada a extrema divulgação dos escritos de Erasmo, bem como sua preocupação concentrada com o ensino e a catequese, seria de se admirar que os jesuítas, cujo contato com esse humanismo já foi evidenciado, não aprovassem tal ênfase e vissem, nela, uma confirmação de sua própria leitura da tradição católica. Muito dificilmente a referência, inserida por Nóbrega nessa carta, não traria à mente de qualquer leitor culto daquele contexto a lembrança da ênfase erasmiana nos poderes da instrução - uma ênfase que, como já sugerimos, ao refletirmos sobre o lugar da instrução religiosa entre as preocupações erasmianas, jamais se limitaria apenas à educação civil das crianças nos "boni mores", "bons costumes".

A importância que os jesuítas atribuíam ao doutrinamento prévio para a correta administração do batismo transparece, com clareza, no trecho a seguir: "El Padre", escreve o irmão leigo Pero Correia, "tiene acá hechas muchas ánimas christianas y toviera toda esta geração con que comarcamos, o la mayor parte della, si no veniera a esta tierra solo como vino, porque no quiere baptizar ninguno hasta primero doctrinarle" (CORREIA apud LEITE, 1954-1958, v. I, p. 226, grifos nossos). ${ }^{31}$ Correia se refere, aqui, ao padre Leonardo Nunes, um dos pioneiros na região de São Vicente. Note-se que os batismos ocorrem, então ("tiene acá hechas muchas ánimas christianas"; "fazer cristão" é sinônimo de batizar); mas ocorrem conjugados a uma determinada prática catequética, e não de forma prévia e independente da instrução. Na sequência, é o próprio padre Leonardo Nunes quem escreve: " $Y$ por no andar ya enseñándolos se perdieron muchas ánimas, porque son grandíssimos los deseos que tienen de conoscer a Dios y de saber lo que han de hazer para salvarse" (NUNES apud LEITE, 1954-1958, v. I, p. 234-235, grifos nossos). ${ }^{32}$

A declaração reveste-se de uma seriedade que o provável tom retórico, que visava ao contínuo despertamento de vocações, não consegue apagar. Muitas almas que se perdem porque, não sendo ensinadas, não podem ser "feitas cristãs": mesmo que essa descrição não possa ser tomada como retrato da missionação jesuítica como um todo, nem como indicação de que nunca teriam ocorrido batismos realizados com reduzida ou insuficiente catequese, as palavras do jesuíta sinalizam, sem dúvida, uma atribuição de importância ao trabalho catequético que não pode ser ignorada.

Consideremos o fragmento a seguir, que demonstra já alguma experiência com a "inconstância" indígena:

Muchos de los gentiles piden el agua del baptismo, mas el $P$. Nóbrega ha ordenado que primero se les hagan los cathecismos y 
exorcismos, hasta tanto que conozcamos en ellos firmeza, y que de todo coraçón crean en Christo, y también que primero emienden sus malos costumbres. Son tales los baptizados que perseveran, que es mucho para dar gracias al Señor, porque aunque desonrrados y vituperados de los suyos, no dexan de perseverar en nuestra obediencia y crecer en buenos costumbres (PIRES apud LEITE, 1954-1958, v. I, p. 252-253, grifos nossos). ${ }^{33}$

A afirmação de António Pires é contundente: "tais são os batizados que perseveram", a saber, os que recebiam adequada instrução catequética. A novidade da empreitada impunha, sem dúvida, acertos ao longo do caminho. O interesse dos indígenas não poderia ser tomado, à parte da doutrinação, como condição para o sacramento. Submeter esse interesse ao crivo de um ensinamento mais detalhado seria imperativo para impedir o retorno dos catecúmenos às práticas gentílicas. De toda forma, o que transparece é que, se nos primeiros momentos do contato entre jesuítas e indígenas o sacramento do batismo foi ministrado mais prontamente, isso se deu por uma confiança precipitada na avidez demonstrada pelos indígenas; não por falta de atenção para com a catequese, nem por conta de qualquer ênfase milenarista que descansasse apenas sobre o batismo para a constituição de um novo povo cristão na América. Ao contrário dessa confiança, algo mística nos efeitos do sacramento, largamente evidenciada no contexto da missionação franciscana na Nova Espanha, o que encontramos entre os jesuítas na América portuguesa é, desde logo, uma preocupação com a "reverência" devida ao sacramento do batismo:

E os que se agora bautizão os apartamos em huma Aldea, onde estão os christãos, e tem huma igreja e casa nossa, onde os emsinão, porque não nos parece bem bautizar muitos em multidão, porque a esperientia ensina que poucos vem a lume, e hé maior condenação sua e pouca reverentia do sacramento do batismo (NÓBREGA apud LEITE, 1954-1958, v. I, p. 346, grifos nossos). ${ }^{34}$

Note-se que esse tom, já indicador da preocupação com a "politia christiana" que caracterizará a missionação jesuítica nos anos seguintes e se consubstanciará, sobretudo, na estratégia dos aldeamentos, encontra-se presente cerca de três anos após o início da missão brasílica, como atesta a data da carta; todavia, é mesmo mais antigo, uma vez que a preocupação com a instrução na fé já foi assinalada em documentos anteriores. Além do mais, se havia um lugar onde importava alardear os números das conversões, esse lugar seria, sem dúvida, na correspondência dirigida ao monarca, patrocinador das missões nos domínios do Império português. Ao contrário, Nóbrega parece preocupado, contra quaisquer ênfases nos batismos de massa, em destacar a importância de um adequado ensino prévio.

Sabemos que as dificuldades com os indígenas mais idosos, vistos pelos missionários como reincidentes "com teimosia" em seus velhos costumes, levaram os jesuítas a um ajuste estratégico, priorizando a catequese dos jovens:

Aunque trabajemos que todos vengan a conocimiento de nuestra fe, y a todos la enseñemos, que la quieren oyr, e della se aprovechar: principalmente pretendemos de enseñar bien los moços. Porque estos bien doctrinados y acustumbrados en virtud, serán firmes y 
constantes, los quales sus padres dexan enseñar, y huelgan con esso (NÓBREGA apud LEITE, 1954-1958, v. I, p. 268). ${ }^{35}$

Os jovens seriam, portanto, matéria mais dúctil para o ensino, na exata proporção em que fossem afastados das antigas práticas, nas quais seus pais e parentes tinham estado imersos. Dar prioridade aos moços não significava, obviamente, excluir os demais; ao contrário, trabalhava-se para que todos chegassem ao "conocimiento da fé". Transmitir, pela via da catequese, os elementos fundamentais para esse "conhecimento" era, portanto, imprescindível.

Um exemplo do conteúdo dessa doutrinação pode ser encontrado na seguinte carta, enviada da Bahia pelo jesuíta Vicente Rodrigues aos "padres e irmãos de Coimbra" (17 de setembro de 1552):

\begin{abstract}
El modo que tengo con ellos es este: Trabajo de adquirir la voluntad de los principales y después les platico a lo que vengo, que es ensennarles la palabra de Dios y lo que manda y quiere Dios que se haga, y diguoles que los que Dios ama saben sus secretos, y otras cosas de que siento moverse a oír la palabra de Dios. Declároles la criación del mundo, y la encarnación del Hijo de Dios y del diluvio que pasó, del qual diluvio dexaron dicho seus antepassados alguna cosa, y también les diguo del día del juicio. Mucho se maravilham por ser cosa que nunca oieron. Ensénamosles la doctrina christiana por la lengua yo y algunos hermanitos de la tierra que comiguo andan, como les Ihamamos (RODRIGUES apud Leite, 1954-1958, v. I, p. 410)
\end{abstract}

Em outra carta ao soberano português, escrita por Nóbrega em 1553, lemos: “E do mar dez legoas poco mais ou menos, [...] ajuntamos todos os que Nosso Senhor quer trazer à sua Igreja e aquelles que sua palavra e evangelho engendra polla pregação" (NÓBREGA apud LEITE, 1954-1958, v. II, p. 16, grifo nosso). ${ }^{36}$

Os caminhos da catequese efetiva passavam, portanto, não apenas pela prioridade dada aos mais jovens, mas também pela estratégia do "ajuntamento". No dizer de Eisenberg, este seria o registro do projeto desenvolvido por Nóbrega e Anchieta em São Vicente e que teria sido seminal para a estratégia dos aldeamentos (Eisenberg, 2000, p. 89; também Castelnau-L'Estoile, 2006, p. 113-122, 273-301). Como demonstram os documentos que apresentamos, tais conceitos já vinham sendo trabalhados pelos jesuítas. Assim, a viragem metodológica, tradicionalmente associada à desilusão com o que se esperava ser uma rápida evangelização dos índios e que se consubstanciou no texto de Nóbrega conhecido como "Diálogo sobre a conversão do gentio" (Leite, 1954-1958, v. II p. 317-345), representou de fato uma mudança de estratégia, mas não uma mudança de eixo central. Nóbrega convenceu-se de que o esforço catequético era desperdiçado por causa da liberdade que o índio tinha de ir-se, fazendo cair por terra todo o trabalho edificado; assim, sua proposta passou a ser o uso do poder secular para garantir o ajuntamento dos indígenas e proporcionar, dessa forma, uma audiência para a catequese. Não há, no entanto, nenhuma mudança em termos da importância do trabalho catequético: a catequese era feita antes e continuou a ser feita depois. No que respeita à instrução catequética, tratou-se da con- 
solidação de uma perspectiva, e não de algum tipo de guinada súbita em relação ao que vinha sendo realizado.

Nesse sentido, é interessante notar que as propostas que Nóbrega formalizou no “Diálogo" e também na célebre carta ao padre Miguel de Torres, conhecida como "Plano Civilizador", (NÓBREGA apud LEITE, 1954-1958, v. II, p. 445-459)37 já podem ser antecipadas, nas Cartas, em vários outros momentos. Na carta que escreveu ao rei D. João III, em julho de 1552, Nóbrega já sinalizava essas medidas futuras ao sugerir que fosse vedado o comércio ("resgate") com os brancos como estratégia para a evangelização: "e se os obrigarem a serem christãos pera poderem resgatar [comerciar], facilmente o farão, e já agora o farião se Iho defendessem [vedassem]" (NÓBREGA apud LEITE, 1954-1958, v. l, p. 347). ${ }^{38}$ Um pouco antes, o padre já havia idealizado uma situação em que os indígenas seriam "senhoreados" pela presença de um número maior de brancos na colônia e, dessa forma, acabariam mais facilmente conduzidos ao evangelho:

Pera mim tenho por averiguado que, se vierem moradores, que este gentio se senhoreará facilmente, e serão todos christãos se, vindo elles, se defender [vedar] resgatar com os gentios, permitindo-se somente resgatar com os christãos e cathecuminos que viverem apartados dos outros, debaixo da obedientia de um pai que os reja, e de hum Padre nosso que os doutrine [...] (NÓBREGA apud Leite, 1954-1958, v. I, p. 346-347).

Pero Correia, de São Vicente, expressa a mesma ideia em sua carta de 10 de março de 1553 ao padre Simão Rodrigues:

Una cosa se puede hazer para los obligar a ser christianos y a se subjectar a dar la obediencia al Rei y a sus justicias, [...] y es mandar S[ua] A[lteza] que sob pena de muerte ningún christiano diese a indio ninguno de la Baya ni un anzuelo, ni cosa ninguna de ninguna calidad; y, haziéndolo ansí, yo confío que antes de mucho tiempo los pusiese debaxo del jugo de nuestro Rei del cielo e del de la tierra (CORREIA apud LEITE, 1954-1958, v. I, p. 443). ${ }^{39}$

É digno de nota que essa preocupação já se evidenciava no segundo ano de missionação na América portuguesa. Escrevendo da Bahia em março de 1550, João de Azpilcueta afirmava, sobre os desejos de batismo expressos pelos indígenas:

No obstante todo esto, no dexan de pedir agoa de batismo, principalmente en las Aldeas que yo enseño [...]. Pero alende de otras particulares razones, dos principales me convidan a no les administrar, que son, allende de no teneren rey a quien ovedezcan, de no seren sus casas fixas, de tal manera que las mudan o se mudan ellos adonde y quando quieren (AZPILCUETA apud LEITE, 19541958 , v. I, p. 181). ${ }^{40}$

Aqui, o receio do padre quanto a administrar o batismo insistentemente pedido tem a ver com a tendência nômade dos indígenas, que o jesuíta já parece associar à sua "inconstância". Também Anchieta, após descrever os hábitos dos indígenas em toda a extensão da costa desde Pernambuco, na sua longa carta de 1 de setembro de 1554 ao padre Inácio de Loyola, conclui, após mencionar o que entendia como falta de sujeição do índio a qualquer 
autoridade: "por isso nenhum fruto, ou ao menos pequeníssimo, se pode colher deles, se não se juntar a força do braço secular, que os dome e sujeite ao jugo da obediência" (ANCHIETA apud LEITE, 1954-1958, v. II, p. 114). ${ }^{41}$ É do mesmo Anchieta a conclusão carregada de melancolia, após o retorno temporário do chefe Tibiriçá aos "antigos costumes":

\begin{abstract}
Assim manifestou o fingimento de sua fé, que até então disfarçara, e ele e todos os mais catecúmenos caíram e voltam sem freio aos antigos costumes. Não se pode portanto esperar nem conseguir nada em toda esta terra na conversão dos gentios, sem virem para cá muitos cristãos, que conformando-se a si e a suas vidas com a vontade de Deus, sujeitem os Índios ao jugo da escravidão e os obriguem a acolher-se à bandeira de Cristo (ANCHIETA apud LEITE, 1954-1958, v. II, p. 207). ${ }^{42}$
\end{abstract}

Independente das dificuldades que, em meados da década de 1550, parecem ter tornado os jesuítas cada vez mais convencidos da importância de se criar uma audiência cativa para a catequese, destaca-se o fato de que, assim como a valorização da catequese, a necessidade de algum "ajuntamento" e mesmo do uso de métodos coercitivos para a conversão situam-se entre as percepções comuns a esses missionários, e isso desde o início da empresa evangelizadora. Adiante, discutiremos brevemente o estranhamento que representaria, para o humanismo erasmiano, a adoção de estratégias coercitivas na evangelização. Por ora, cabe destacar, ainda, alguns aspectos curiosos, apresentados pelas cartas que estamos considerando. Em relação aos catecúmenos o costume adotado pelos jesuítas lembrava aquele praticado pelos cristãos nos primeiros séculos, quando somente os batizados eram admitidos à liturgia eucarística, os demais devendo retirar-se após encerrar-se a pregação. Mas, como indica o segundo fragmento a seguir, nem sempre a proibição de assistir à "misa entera" agradava aos indígenas:

\begin{abstract}
Tenemos agora un lugar de Yndios convertidos diez leguas por la tierra dentro [...].[...]La gente dél toda va a la yglesia a oyr misa, todos los domingos y días sanctos: tienen siempre sermón y estación, así como hazen en qualquier parroquia em Portugal. Acabada la estación, van todos a la ofrenda, y sálense los catecúminos y vanse para sus casas, y los christianos quedan oyendo misa entera [...]. Todos los días de la semana tienen doctrina dos vezes en la yglesia (CORREIA apud LEITE, 1954-1958, v. II, p. 69). ${ }^{43}$

Nesta Aldeia, foram admitidos para o catecismo 130 e para o baptismo 36, de toda a idade e de ambos os sexos. Ensina-se-lhes todos os dias duas vezes a doutrina cristã, e aprendem as orações em português e na língua própria deles. [...] Todos os domingos se lhes celebra missa; mas muitos dos catecúmenos levam a mal serem mandados embora depois do ofertório e pedem-nos assiduamente que os admitamos ao batismo. Se o não fazemos é por precaução, para que não voltem ao vómito dos antigos costumes, pois pensamos que o batismo não lhes deva ser concedido senão depois de longa prova (ANCHIETA apud LEITE, 1954-1958, v. II, p. 106-107, grifos nossos) ${ }^{44}$
\end{abstract}

Esta última referência provém de outra carta escrita por Anchieta ao padre Inácio de Loyola. Haverá, nela, uma preocupação em aparar arestas e frisar, retoricamente, a adequação da prática missionária aqui desenvolvida aos ditames da Companhia? Talvez; mas isso, 
em última análise, indicaria apenas que na Companhia como um todo a catequese ocupava lugar de preeminência. Todavia, não nos parece que uma análise atenta do texto, sensível às suas dimensões retóricas, deva fechar os olhos para a evidência de que, mesmo para os soldados da Companhia que aqui labutavam, a instrução na fé tinha importância central.

O meu exercitio nesta povoação era bautizar os ynocentes e enterrar os mortos e ensinar a doutryna a este gentio, casando os amancebados in lege naturae [...]. Trabalhava por aparelhar os velhos e adultos pera receberem o bautismo, e os bautisados ensinava-os e doutrynava-os nas cousas da Fé, aparelhando-os huns e os outros a bem morrer (MELO apud LEITE, 1954-1958, v. II, p. 281). ${ }^{45}$

Nesta declaração do jesuíta João de Melo, o novo e o antigo apresentam-se unidos. Velhos e adultos devem ser "aparelhados" para "receberem o bautismo"; mesmo os batizados precisavam continuar recebendo instrução "nas cousas da Fé". Como não pensar, aqui, na instrução pós-batismal desejada por Erasmo e sobre a qual, como vimos, ele escrevia quarenta anos antes? Eis aí o elemento "novo" colocado pelas missões americanas: curiosamente, um "novo" que recuperava épocas priscas, porque, por artes dessas novas missões, a prática do batismo de adultos que se seguia a uma instrução acurada, lugar-comum nos primeiros séculos da fé cristã, tornava-se outra vez experiência da Igreja. ${ }^{46}$ Mas aqui se encontra presente, também, o elemento da tradição católica: os "ynocentes" são batizados de imediato, porque a prática estabelecida na cristandade era (ou, ao menos, deveria ser, em termos ideais) o batismo do infante, seguido pela instrução em época apropriada. Permeando toda a atividade do jesuíta, vai-se ensinando "a doutryna a esse gentio", vão-se regularizando as relações sociais (as uniões "naturais" ou feitas in lege naturae são reconhecidas, ainda que não tenham sido objeto do sacramento apropriado), catecúmenos e batizados são instruídos de forma "a bem morrer".

Da leitura de nossas fontes depreendemos que a missionação jesuítica baseou-se, desde o início, na catequese, subordinando idealmente o batismo, salvo raras exceções (como nos casos in articulo mortis), a alguma medida de doutrinamento. Não nos compete julgar a eficácia dessa catequese, sobretudo em confronto com o que os missionários denominaram a "inconstância" indígena; tampouco supomos que a preocupação catequética, presente na prática evangelizadora jesuítica, tenha significado a eliminação, de forma homogênea, de batismos realizados sem doutrinação mínima. O que não nos parece correto, à vista das fontes, é a atribuição de um peso maior aos batismos "em massa", como se estes, e não a ênfase catequética, constituíssem o eixo central do modus procedendi jesuítico. Outrossim, ainda quando, sob o influxo do otimismo inicial, os batismos eram mais prontamente realizados, isso não se dava em razão de um aporte "milenarista" no seio da pregação dos jesuítas; a Companhia de Jesus não se apresentava assinalada por esse misticismo e, portanto, não é nessa chave que a prática batismal nos primeiros anos de missionação brasílica deve ser explicada. Finalmente, a preeminência atribuída à catequese pelos jesuítas que aqui labutaram repercutiu, muito de perto, um traço importantíssimo do humanismo erasmiano, fazendo da instrução nas coisas da religião a forma efetiva pela 
qual esse ideário pôde ser integrado ao horizonte da vida intelectual da colônia.

Seria possível inquirir se uma abertura ao humanismo erasmiano, como essa evidenciada pela importância atribuída pelos jesuítas à catequese, poderia coexistir com o uso de medidas coercitivas na evangelização. Sem dúvida, estamos diante de um particular que não indicaria uma estratégia missionária propriamente "erasmiana". Para Erasmo, a necessária evangelização daqueles que se encontravam alheios à cristandade deveria ser feita principalmente por meio do exemplo, dócil, de um comportamento cristão. Esse, e não o emprego da violência, seria o caminho indicado pelo humanista para converter os turcos: "quem é que jamais viu que se tornassem em verdadeiros cristãos homens que foram coagidos pelo ferro, pelo morticínio, pelos incêndios e pelas pilhagens?" (Erasmo, 1999, p. 70). O emprego da força, todavia, como estratégia de convencimento, era lugar-comum naquela época e não poderia ser totalmente descartado; o próprio humanista admitia, caso fosse necessário fazer a guerra aos turcos, "se eles de moto próprio nos atacarem", que então "os turcos sintam que são convidados para a salvação, não guerreados por amor da presa" (Erasmo, 1999, p. 71). Mas a presença de uma estratégia coercitiva na prática jesuítica não deve causar estranheza, sobretudo se José Eisenberg tiver razão em sua tentativa de explicar como os jesuítas conciliaram essa estratégia com a necessária liberdade de decisão que possibilita a conversão cristã (Eisenberg, 2000, p. 116-123). A própria falta de entusiasmo de Erasmo diante de uma evangelização imbuída por esse elemento coercitivo não constrangia a esses jesuítas; afinal, como apropriadores do humanismo erasmiano, sentiam-se livres para se valerem das ênfases que julgavam interessantes nesse ideário, sem qualquer obrigação de repeti-lo em todos os detalhes. ${ }^{47}$

Para os propósitos de nosso estudo, no entanto, esse problema é apenas incidental. Como já ficou claro, os jesuítas em ação na América portuguesa não precisavam concordar integralmente com as posições erasmianas para se apropriarem de aspectos de seu pensamento; e essa apropriação aconteceu, na medida em que o caráter central do ensino para Erasmo foi incorporado pelos jesuítas como um todo, o que se manifestou também nas missões desenvolvidas no Brasil. O que importa perceber, nesse sentido, é que toda a estratégia dos aldeamentos implementada por Mem de Sá não alterou essa disposição básica da prática jesuítica: ela continuou centralizada na catequese. A tarefa primordial dos jesuítas era - e continuou sendo - o ensino. ${ }^{48}$

\section{$-\mathrm{V}-$}

Não é frequente pensarmos nos jesuítas como representantes, em terras brasílicas, de uma vertente importante do humanismo retórico. Nesse sentido, talvez ainda estejamos a ecoar distinções muito nossas - entre "cultura erudita" e "religião", por exemplo - que, de fato, nada diriam aos nossos congêneres do século XVI europeu; isso se não estivermos, pura e simplesmente, dando forma a antigos preconceitos historiográficos.

Na segunda metade do século XVI, em meio às dificuldades e hesitações de um proje- 
to colonial nem sempre claro, nem sempre seguro de si, e que ademais se engendrava no bojo de uma tarefa missionária cuja primazia era universalmente reconhecida, a ação dos jesuítas na América portuguesa representou um caminho, inusitado, para a difusão nestas plagas de um ideário erasmiano que, ainda, animava os debates intelectuais no contexto europeu. Lido e apropriado por tantos em diferentes contextos, esse humanismo exerceu também sua atração sobre os jesuítas, quer pela leitura direta de obras de Erasmo, quer pela leitura de obras que, elas também, apropriavam-se desse ideário e o repercutiam.

Afirmamos, no início, que o índice de uma cultura letrada não passava necessariamente pela posse de livros, mas também pela saudade deles. É fora de dúvida que os livros de que temos saudade falam, e muito, de nós mesmos. Ocupado nas lides missionárias em São Vicente, e sem gozar de uma formação que lhe possibilitasse o acesso a obras latinas, o jesuíta Pero Correia escreveu uma carta em março de 1553 ao provincial da Companhia em Portugal, padre Simão Rodrigues. Após lamentar-se de sua inaptidão na língua latina ("fáltanme libros en lenguage para estudiar, porque non soi latino y no me pudo aiudar de los de latín"), Correia pediu o envio de uma pequena biblioteca de obras do conhecido clérigo Constantino Ponce de la Fuente, famoso pregador da catedral de Sevilha: o pedido listava a Confesión de un pecador, a Doctrina Christiana, a Exposición del primer salmo de David "Beatus Vir", a Suma de Doctrina Christiana e o Catecismo Christiano (CORREIA apud LEITE, 1954-1958, v. I, p. 440-441). ${ }^{49}$ Todos esses textos, como Bataillon bem observa, estavam imbuídos da perspectiva erasmiana. ${ }^{50} \mathrm{O}$ fato de que não podemos saber ao certo se Correia foi atendido não diminui a importância evidenciada pelo pedido: desejoso de aperfeiçoar-se no conhecimento da doutrina para poder catequizar melhor, foi nessas obras que Correia pensou. Terão sido indicadas a ele pelos outros missionários, em especial pelos padres versados no latim? Em carta de 24 de abril de 1552, escrita de Cochim, o padre Francisco Xavier nos garante que ali pelo menos dois jesuítas tinham cópias do "Constantino" (Bataillon, 1996, p. 827). Leite nos lembra que Correia, encontrando-se em São Vicente desde 1542, não podia ter conhecimento prévio de alguns desses textos: os sermões sobre o salmo "Beatus Vir" parecem ser de 1546, enquanto a Suma de Doctrina Christiana é de 1543. ${ }^{51}$ A possibilidade de que os textos tenham sido indicados a Correia pelos padres parece-nos, portanto, mais do que plausivel. Por caminhos tais se processava, direta ou indiretamente, a divulgação do ideário erasmiano. Se podemos falar de um "Erasmo brasílico" no contexto da segunda metade do século XVI, nós o faremos numa conexão que já foi considerada, por muitos, como improvável: aquela da missionação jesuítica conduzida nestas paragens.

\section{Referências}

\section{Fontes}

AGOSTINHO. De Ciuitate Dei. Ed. José Moran. Madrid: Biblioteca de Autores Cristianos, 1964. 
BARROS, João de. Asia de Joam de Barros: Dos fectos que os Portugueses fizeram no descobrimento e conquista dos mares e terras do Oriente. Primeira década. Reedição da edição de António Baião. Lisboa: Imprensa Nacional/Casa da Moeda, 1988.

ERASMO. De Pueris. Tradução de Luiz Feracine. São Paulo: Escala, 2006.

ERASMO. Dulce bellum inexpertis (A guerra é doce para os que a desconhecem). In: ERASMO. A Guerra e a queixa da paz. Introdução, tradução do latim e notas de A. Guimarães Pinto. Lisboa: Edições 70, 1999. p. 25-78.

ERASMO. Ecclesiastae siue De ratione concionandi libri quatuor. Basileae: Froben, 1535.

ERASMO. Enchiridion Militis Christiani. Coloniae: Apud Haeredes Arnoldi Birckmani, 1563.

ERASMO. Enquiridion: Manual del Cabalero Cristiano. Tradução de Pedro Rodriguez Santidrian. Madrid: Biblioteca de Autores Cristianos, 1995.

ERASMO. Ichthyophagia. In: ERASMO. Opera omnia Desiderii Erasmi Roterodami recognita et adnotatione critica instructa notisque illustrata. Amsterdam: North Holland Publishing Company, 1969 , t. I, v. 3, p. 495-536.

ERASMO. In evangelium Matthaei paraphrasis. Leiden: Seb. Gryphium, 1544.

ERASMO. Serenissimo Lusitaniae Regi loanni. In: ERASMO. Diui loannis Chrysostomi Archiepiscopi Constantinopolitani \& diui Athanasii Alexandrini Archiepiscopi lucubrationes aliquot non minus elegantes quam utiles, nunc primum uersae \& in lucem aeditae per Des. Erasmum Roterodamum. Basileae: Apud Ioan. Frobenium, 1527. fls. a-a5.

GÓIS, Damião de. Breve contestação de Damião de Góis a Paulo Jóvio sobre o domínio dos portugueses. In: GÓlS, Damião de. Opúsculos Históricos. Tradução de Dias de Carvalho. Porto: Livraria Civilização Editora, 1945. p. 85-89.

LEITE, Serafim (Org.). Cartas dos primeiros jesuítas do Brasil. São Paulo: Comissão do IV Centenário da Cidade de São Paulo, 1954-1958. 3 v.

MOTOLINÍA, Frei Toríbio de Benavente. Memoriales o libro de las cosas de la Nueva España y de los naturales de ella. 2. ed. Edição crítica, notas e estudo introdutório por Edmundo O Gorman. Cidade do México: Universidad Nacional Autónoma de México, 1971. Bibliografia Subsidiária

AGNOLIN, Adone. Jesuítas e selvagens: A negociação da fé no encontro catequético-ritual 
americano-tupi (séc. XVI-XVII). São Paulo: Humanitas, 2007.

BATAILLON, Marcel. De Erasmo a la Compañia de Jesús: protesta y integración en la Reforma católica del siglo XVI. In: BATAILLON, Marcel. Erasmo y el erasmismo. 2. ed. Barcelona: Editorial Crítica, 1983. p. 203-244.

BATAILLON, Marcel. Erasmo y España: Estudios sobre la historia espiritual del siglo XVI. México: Fondo de Cultura Económica, 2ª . edição (1966), 2ª . reimpressão, 1996 (edição original francesa, 1937; primeira edição em espanhol, 1950).

BERNAND, Carmen; GRUZINSKI, Serge. História do Novo Mundo. São Paulo: Edusp, 2001. BOSCHI, Caio. Estruturas eclesiásticas e Inquisição. In: BETHENCOURT, Francisco; CHAUDHURI, Kirti. História da Expansão Portuguesa. Lisboa: Círculo de Leitores e Letras, 1998. v. 2, p. 429-452.

CASTELNAU-L'ESTOILE, Charlotte de. Operários de uma vinha estéril: Os jesuitas e a conversão dos índios no Brasil - 1580-1620. Tradução de Ilka Stern Cohen. Bauru: Edusc, 2006.

CASTRO, Eduardo Viveiros de. O mármore e a murta: sobre a inconstância da alma selvagem. In: CASTRO, Eduardo Viveiros de. A inconstância da alma selvagem e outros ensaios de antropologia. São Paulo: Cosac \& Naify, 2002. p. 183-264.

$\mathrm{COHN}$, Norman. The Pursuit of the Millenium: Revolutionary Millenarians and Mystical Anarchists of the Middle Ages. Revised and Expanded Edition. New York: Oxford University Press, 1970.

DALEY, Brian E. Apocalypticism in Early Christian Theology. In: MCGINN, Bernard (Ed.). The Encyclopedia of Apocalypticism. New York/London: Continuum, 1998, v. 2, p. 3-47.

DELUMEAU, Jean. Les Chrétiens au temps de la Réforme. In: DELUMEAU, Jean. Un chemin d'histoire: Chrétienté et Christianisation. Paris: Fayard, 1981. p. 13-29.

EISENBERG, José. As missões jesuíticas e o pensamento político moderno: encontros culturais, aventuras teóricas. Belo Horizonte: Editora da UFMG, 2000.

FARIA, Patrícia Souza de. Os concílios provinciais de Goa: Reflexões sobre o impacto da "Reforma Tridentina" no centro do império asiático português (1567-1606). Topoi, Rio de Janeiro, v. 14, n. 27, p. 218-238, 2013.

FRIESEN, Abraham. Erasmus, the Anabaptists, and the Great Commission. Grand Rapids, MI, EUA: Eerdemans, 1998. 
GASBARRO, Nicola. A Modernidade ocidental e a generalização de "religião" e "civilização": o agir comunicativo das missões. In: ALMEIDA, Néri de Barros; SILVA, Eliane Moura da (Org.). Missão e Pregação: A comunicação religiosa entre a História da Igreja e a História das Religiões. São Paulo: Fap-Unifesp, 2014. p. 189-210.

GODIN, André. Érasme, Lecteur d'Origène. Genève: Librairie Droz, 1982.

HALKIN, Léon E. Erasme parmi nous. Paris: Fayard, 1987.

HAMMAN, Adalbert-Gautier. A vida cotidiana dos primeiros cristãos (95-197). Tradução de Benôni Lemos. São Paulo: Paulus, 1997.

HANSEN, João Adolfo. Introdução. In: VIEIRA, Antônio. Cartas do Brasil. Organização de João Adolfo Hansen. São Paulo: Hedra, 2003. p. 7-74.

HOFFMANN, Manfred. Rhetoric and Theology: The Hermeneutics of Erasmus. Toronto: University of Toronto Press, 1994.

HOLANDA. Visão do Paraíso: Os Motivos Edênicos no Descobrimento e Colonização do Brasil. São Paulo: Publifolha/Brasiliense, 2000.

HORTA, José da Silva. Uma leitura de Zurara por João de Barros. In: Vv. Aa. Amar, Sentir e Viver a História: Estudos de Homenagem a Joaquim Veríssimo Serrão. Lisboa: Edições Colibri, 1995. v. II, p. 673-702.

JEDIN, Hubert. Historia del Concilio de Trento. Pamplona, Espanha: Universidad de Navarra, 1972-1981. 5 v.

KOHLS, Ernest-Wilhelm. Die Theologie des Erasmus. Basel, Schweizland: Friedrich Reinhadt, 1996. 2 v.

KRISTELLER, Paul Oskar. Renaissance Thought and its Origins. New York: Columbia University Press, 1979.

KRISTELLER, Paul Oskar. The Classics and Renaissance Thought. Cambridge: Harvard University Press, 1955.

LEFF, Gordon. The Apostolic Ideal in Later Medieval Ecclesiology. In: LEFF, Gordon. Heresy, Philosophy and Religion in the Medieval West. Aldershot, UK: Ashgate Publishing, 2002. p. 58-82. 
MACHADO, José de Alcântara. Vida e Morte do Bandeirante. São Paulo: Martins; Brasília: Instituto Nacional do Livro, 1972.

MARKUS, Robert A. O fim do cristianismo antigo. Tradução de João Rezende Costa. São Paulo: Paulus, 1997.

MCCONICA, James. Erasmus. In: THOMAS, Keith (Ed.). Renaissance Thinkers. Oxford: Oxford University Press, 1993. p. 5-112.

MOSS, Ann. Renaissance Truth and the Latin Language Turn. Oxford: Oxford University Press, 2003.

O'MALLEY, John W. Os primeiros jesuitas. Tradução de Domingos Armando Donida. São Leopoldo, RS/Bauru, SP: Editora Unisinos/EDUSC, 2004.

O'MALLEY, John W. Trent and All That: Renaming Catholicism in the Early Modern Era. Cambridge, MA: Harvard University Press, 2002.

O'MALLEY, John W. Was Ignatius of Loyola a Church Reformer? How to look at Early Modern Catholicism. Catholic Historical Review, v. 77, p. 177-193, 1991.

OVERFIELD, James H. Humanism and Scholasticism in Late Medieval Germany. Princeton, NJ: Princeton University Press, 1984.

PAIVA, José Pedro. Os bispos de Portugal e do Império, 1495-1777. Coimbra: Imprensa da Universidade de Coimbra, 2006.

PALOMO, Federico. A Contra-Reforma em Portugal, 1540-1700. Lisboa: Livros Horizonte, 2006.

POMPA, Cristina. Religião como Tradução: Missionários, Tupi e Tapuia no Brasil colonial. Bauru: EDUSC, 2003.

PROSPERI, Adriano. /l Concilio di Trento: uma introduzione storica. Torino, Itália: Einaudi, 2001.

PROSPERI, Adriano. Tribunali della coscienza: Inquisitori, Confessori, Missionari. Torino, Itália: Einaudi, 1996.

RAFAEL, Vicente L. Contracting Colonialism: Translation and Christian Conversion in Tagalog Society under Early Spanish Rule. Ithaca, NY, EUA: Cornell University Press, 1988. 
RODRIGUES, Rui Luis. Cidade Sitiada: O cerco militar no século XVI como espaço de utopia e de contra-utopia - Os exemplos de Münster (1534-1535) e de Sancerre (1573). Revista de História, São Paulo, n. 176, p. 1-34, abr. 2017b. Disponível em: <http://www.revistas.usp.br/ revhistoria/article/view/116661/127886>. Acesso em: 16 maio 2017.

RODRIGUES, Rui Luis. Entre o dito e o maldito: Humanismo erasmiano, ortodoxia e heresia nos processos de confessionalização do Ocidente, 1530-1685. 2012. 614 f. Tese (Doutorado em História Social) - Faculdade de Filosofia, Letras e Ciências Humanas, Universidade de São Paulo, São Paulo, 2012.

RODRIGUES, Rui Luis. Os processos de confessionalização e sua importância para a compreensão da história do Ocidente na primeira modernidade (1530-1650). Tempo [on-line], Niterói, v. 23, n. 1, p. 1-21, 2017a. Disponível em: <http://www.scielo.br/scielo. php? script=sci_arttext\&pid=S1413-77042017000100001\&lng=pt\&nrm=iso $>$. Acesso em: 4 maio 2017.

RUMMEL, Erika. Erasmus' Annotations on the New Testament: From Philologist to Theologian. Toronto: University of Toronto Press, 1986.

RUMMEL, Erika. The Humanist-Scholastic Debate in the Renaissance and Reformation. Cambridge, MA; London, UK: Harvard University Press, 1995.

SKINNER, Quentin. As fundações do pensamento político moderno. São Paulo: Companhia das Letras, 1996 (4a. reimpressão, 2003).

TILLARD, Jean-Marie. La Iglesia Local: Eclesiologia de Comunión y Catolicidad. Salamanca, Espanha: Sígueme, 1999.

TOLEDO, Maria Fátima de Melo. O sonho da quimera: uma análise do "Diálogo sobre a conversão do gentio" do Pe. Manuel da Nóbrega. 2000. Dissertação (Mestrado em História Social) - Faculdade de Filosofia, Letras e Ciências Humanas, Universidade de São Paulo, São Paulo, 2000.

VILLALTA, Luiz Carlos. O que se fala e o que se lê: Língua, instrução e leitura. In: NOVAIS, Fernando A. (Org.). História da Vida Privada no Brasil. Organização do volume de Laura de Mello e Souza. São Paulo: Companhia das Letras, 1997. v. 1, p. 331-385. (Cotidiano e vida privada na América portuguesa).

WILLIAMS, George H. La Reforma Radical. Tradução de Antonio Alatorre. México: Fondo de Cultura Económica, 1983. 


\section{Notas}

1 Villalta (1997, p. 334) observa com acerto que tanto o controle mais afiado sobre a circulação de livros como uma política de difusão da língua portuguesa correspondem a medidas adotadas mais claramente pela administração portuguesa a partir do século XVIII.

2 Para a noção de "processos de confessionalização", ver Rodrigues (2012, p. 370-452) (com bibliografia); para Trento como expressão da confessionalização católica, ver Rodrigues (2017a, p. 4). Como exemplos desses novos estudos aqui referidos, que têm mirado a missionação jesuítica como importante paradigma para a compreensão dos encontros culturais na primeira modernidade, ver Agnolin (2007); Pompa (2003); Gasbarro (2014). Para a importância do sacramento da confissão a partir do concílio de Trento, e em especial seu uso como instrumento de "controle das consciências", ver Agnolin (2007, p. 99-107; 179-184; 311-321); Prosperi (1996, p. 213-548).

3 "Esquematizar a Reforma católica, de Lutero em diante", escrevia Marcel Bataillon, em 1949, "como Contrarreforma, equivale a empobrecê-la, e o fato de que a Companhia de Jesus, após 1560, tenha sido uma grande força antiprotestante, não significa que santo Inácio tenha sido, mais do que qualquer outra coisa, um antiLutero" (Bataillon, 1996, p. xiv). Para uma sintese da revisão crítica empreendida pela historiografia, nas últimas décadas, em torno dos conceitos de "reforma" e "contrarreforma", ver Rodrigues (2012, p. 36-43). Como exemplo dessa revisão, basta mencionar a posição do historiador John O'Malley, para quem o uso lato das expressões "reforma" e "contrarreforma", no âmbito do catolicismo, deveria ser substituído pelo conceito de "Early Modern Catholicism". Ver a propósito O’Malley (1991, p. 185, 191-193); O’Malley (2002).

4 Ver também Bataillon (1996, p. 1-71, 166-225); para uma relativização dessa perspectiva, que, todavia, não menciona Bataillon, ver O'Malley (2004, p. 405-406). Para a proposta erasmiana de síntese entre Antiguidade e fé cristã, ver Rodrigues (2012, p. 103-131); Rummel (1986); Hoffmann (1994). A compreensão atual da "vertente retórica" do humanismo europeu do Quatrocentos e do Quinhentos depende imensamente dos trabalhos de Paul Oskar Kristeller; ver em especial Kristeller (1955); Kristeller (1979). Para as transformações experimentadas por esse humanismo na passagem do século XV para o XVI, ver em especial Rummel (1995); Overfield (1984); Moss (2003). Para o Enchiridion Militis Christiani ou "Manual do soldado cristão", texto publicado por Erasmo em 1504, mas cuja reedição por Froben, em 1518, teve impacto importantíssimo, ver Erasmo (1563); Erasmo (1995); discutimos extensamente essa obra erasmiana, com revisão da bibliografia mais relevante, em Rodrigues, 2012, p. 46-63 (a propósito de seu alegado "espiritualismo") e p. 207-232 (para a representação de sociedade cristã veiculada por ela).

5 Para a noção de "apropriação" aqui utilizada, que compreende a apropriação como resultado do esforço criativo da leitura no embate entre o mundo colocado pelo texto e o mundo constituído pelos pressupostos do leitor, ver a discussão teórica em Rodrigues (2012, p. 456-467). É sem dúvida em razão da dependência de Bataillon para com a noção de "influência" que um autor como John O'Malley minimiza uma participação erasmiana nas origens da Companhia de Jesus. Em seu lugar, fala de forma por demais generalizante e insatisfatória sobre a presença de "concepções humanistas" no ideário jesuítico. Ver O’Malley (2004, p. 18, 32, 34-35, 394-411).

6 É importante mencionar que as críticas, bastante justas, que Cristina Pompa faz a Serafim Leite enquanto tradutor (ver Pompa, 2003, p. 412-414), dizem respeito principalmente ao material apresentado no tomo $\mathrm{V}$ da História da Companhia de Jesus no Brasil. Lisboa/Rio de Janeiro: Livraria Portugália/Civilização Brasileira, 19381950. 10 v, e não se aplicam às cartas sob consideração neste estudo. Efetivamente, no corpus documental, o único documento traduzido por Leite (do latim) é a carta escrita por Anchieta a Inácio de Loyola (ver abaixo, nota 42). De resto, as observações críticas feitas neste artigo ao trabalho de Cristina Pompa não ignoram a enorme e original contribuição trazida por sua pesquisa para os conhecimentos sobre a prática missionária na América portuguesa.

7 O Diálogo sobre a conversão do gentio, de Nóbrega, encontra-se em Leite (1954-1958, v. II p. 317-345). A propósito, ver Toledo (2000); Eisenberg (2000, p. 116-123); Castelnau-L'Estoile (2006, p. 102-113).

8 Sobre Trento, ver Jedin (1972-1981); Prosperi (2001). Para a difusão das disposições tridentinas nos territórios portugueses, ver Paiva (2006, p. 128-139); Palomo (2006); Boschi (1998); Faria (2013); para as relações entre Trento e os jesuitas, ver O'Malley (2004, p. 493-503).

9 A complexa trajetória de Erasmo de Rotterdam vai de autor mais impresso de seu tempo, a partir da publicação de obras capitais como sua edição crítica do Novo Testamento (Nouum Instrumentum, 1516), a edição do Enchiridion por Froben (1518) e a edição, também por Froben, dos Colloquia (Familiarium Colloquiorum Formulae, 1522), até sua classificação como auctor damnatus primae classis e a inclusão de vários de seus textos no Index romano do papa Paulo IV (1559). Nesse intervalo, Erasmo foi celebrado em correspondência imperial, datada de 14 de dezembro de 1527, como aquele que teria realizado "sozinho", em defesa da "república cristã", "o que por 
imperadores, pontífices, príncipes, universidades e por tantos e tão assinalados varões até agora não se pudera alcançar". Ver Mcconica (1993, p. 108); Halkin (1987, p. 271-325); Bataillon (1996, p. xiv) (para a condenação de Erasmo como auctor damnatus) e p. 277-278 (para a carta de reconhecimento imperial; a citação acima encontra-se na p. 277). Para a recepção, bastante negativa, do Índice de 1559 por parte dos jesuítas, haja vista a presença de muitas obras erasmianas nas bibliotecas dos colégios da Companhia, ver O'Malley (2004, p. 482484).

10 Ver Eisenberg (2000, p. 53-56); Castelnau-L'Estoile (2006, p. 72-76); Pompa (2003, p. 81-84). Sobre a ars dictamini, ver ainda Skinner (1996, p. 45-69, esp. p. 50-55).

11 Para maiores detalhamentos, ver Rodrigues (2012, p. 318-349).

12 "Nunc multi sunt quinquagenarij, qui nesciant quid uouerint in baptismo: qui ne somniarint quidem, quid sibi uelint articuli fidei, quid precatio dominica, quid Ecclesiae sacramenta" (ERASMO, 1544, p. 20). Neste artigo, salvo indicação em contrário, todas as traduções do latim são de minha responsabilidade. Para a instrução pós-batismal proposta por Erasmo, mencionada a seguir, ver Erasmo (1544, p. 18-19).

13 De forma mais cuidadosa, Williams (1983, p. 21-28).

14 Bataillon (1996, p. 807-831) ("Erasmo e o Novo Mundo"); na carta que dedicou ao rei de Portugal, D. João III, sua edição dos sermões de João Crisóstomo, Erasmo referiu-se positivamente à maneira pela qual o monarca "pacificou um vastíssimo oceano" ("uastissimum pelagus [...] adeo pacatum reddidit"), o que teria tornado possivel espalhar "em vários locais a sementeira da piedade católica" ("sparso uarijs in locis Catholicae pietatis seminario"; ERASMO, 1527, fl. a). Já o colóquio Ichthyophagia, de 1526, revela um viés mais crítico; nele, o personagem Lanio, instado a se manifestar sobre as praias e ilhas austrais que se encontravam assinaladas por bandeiras cristãs ("totum illud littus Austrinum et sparsas insulas Christianis insignibus notatas"), responde: "Vi-as e soube que delas tiraram despojos, não ouvi que lá tenham introduzido o Cristianismo". ("Vidi, didicique illinc auectas praedas, Christianismum inductum non audiui"; Erasmo, 1969, p. 504-505).

15 "Docendi uox complectitur \& doctrinam sanam, \& admonitionem, \& increpationem, \& consolationem, \& redargutionem oblatrantium Euangelicae ueritati. Baptizat $\&$ laicus, orat uicissim pro sacerdote populus, non difficilis est reliquorum sacramentorum administratio: at docendi munus implere, ut longe difficillimum est, ita idem est longe pulcherrimum, quippe cuius utilitas latissime pateat. Non semper tingit, non semper ungit aut absoluit sacerdos, sed docendi munus perpetuum est, sine quo caetera sunt inutilis. Quid enim prodest adultis tinctos esse, nisi per catechistam docti fuerint, quam uim habeat baptismus, quid oporteat credere, quomodo iuxta professionem Christianam uitam instituere? Quid prodest sumptio corporis et sanguinis dominici, nisi didicerint, quomodo sacramentum hoc institutum, quid in nobis efficiat, qua fide, quaque puritate debeat sumi?" (Erasmo, 1535, p. 82).

16 Para a presença de Erasmo nos colégios jesuíticos, ver O'Malley (2004, p. 483); para a designação de Laínez e Salmerón como teólogos do concílio de Trento, ver O’Malley (2004, p. 497-500) (é digno de nota que Salmerón e Laínez tenham estado entre os poucos clérigos que participaram de todas as sessões do longo concílio de Trento); para Salmerón como leitor de Erasmo, ver O’Malley (2004, p. 410). Sabe-se que Laínez leu de Erasmo o Modus orandi Deum e que Polanco, outro jesuíta de destaque, secretário pessoal de Inácio de Loyola desde 1547, leu o Ecclesiastae e a Paráfrase sobre o Evangelho de Mateus (ver O'Malley, 2004, p. 409).

17 Para o Índice de Pio IV, ver O'Malley (2004, p. 483); para a importância da pregação no âmbito das atividades dos jesuitas, ver O'Malley (2004, p. 146-174).

18 A tradução da referência é: "E será pregado este evangelho do reino em todo o mundo, em testemunho a todos os povos, e então virá o fim". "Consummatio" é o termo utilizado pela Vulgata para traduzir o grego "tò télos". Para a insistência de Pompa na "visão apocalíptico-milenarista" como "nunca abandonada pelos missionários" e a tendência da autora no sentido de ler em chave milenarista todo um conjunto de práticas e crenças católicas que não depende necessariamente dessa chave, ver Pompa (2003, p. 403).

19 A bibliografia sobre este tema, tanto de fundo histórico quanto teológico, é imensa. Ver, sinteticamente, Daley (1998, esp. p. 19-35). Para a identificação que Agostinho faz entre o Milênio e o "presente reino" da Igreja, ver Agostinho (1964, XX, 9). Para uma compreensão sobre "milenarismo" que se tornou paradigmática nos estudos históricos e sociológicos, ver Cohn (1970, esp. p. 19-36). Considero problemático o uso, algo indiscriminado, que se faz do rótulo "milenarismo"; ver a propósito Rodrigues (2017b, p. 6-7) (esp. nota 11) e p. 11-12 para um uso mais específico da noção de "apocalíptico" (para bibliografia, ver RODRIGUES, 2017b, p. 11-12 nota 19).

20 Ver Pompa (2003, p. 62) para a expressão entre aspas. A referência da autora é à Crônica da Companhia de Jesus, do padre Simão de Vasconcelos (1663).

21 “Não virá, pois, o fim do mundo antes que este evangelho do reino dos céus seja pregado em todos os reinos 
do mundo, e tome posse de todas as nações". Para uma análise similar, ver Bataillon (1996, p. 816, nota 40).

22 Manuel da Nóbrega, "Carta aos moradores de Pernambuco. Da Bahia, 5/6/1552".

23 Vicente Rodrigues, "Carta aos padres e irmãos de Coimbra. Da Bahia, 17/9/1552".

24 Para uma referência aos milhares de batismos realizados nos primeiros anos de evangelização do México, cf. Motolinía (1971, p. 122ss) (cf. especialmente os parágrafos 195, 199, 202, 204 e 215 a 218); para uma análise crítica desses batismos, cf. Bernand e Gruzinski (2001, p. 419).

25 A esse respeito, ver Castro (2002). O trabalho de Eduardo Viveiros de Castro apresenta limitações evidentes do ponto de vista histórico; sua tese, bastante sugestiva, é de que a "inconstância" identificada pelos europeus se explicaria em termos de uma sociedade pautada pela identificação com os outros, e não consigo mesma (CASTRO, 2002, p. 195-196). Já Cristina Pompa vê nessa pretensa "inconstância" uma característica da abordagem indigena, cuja "prática", diferentemente do cristianismo, não depende necessariamente de uma "crença"; daí, segundo a autora, a tendência nos indígenas de desejarem o cristianismo sem abandonarem suas próprias práticas. Cf. Pompa (2003, p. 95-96, 361).

26 Para um exemplo dessa cautela, mesmo no caso de um agonizante, cf. José de Anchieta, "Carta ao padre Diego Laynez, Roma. De S. Vicente, 1/6/1560". In: Leite (1954-1958, v. III, p. 249-250).

27 De fato, parece ter havido um uso "não-sacramental" da confissão, como depreendemos de um trecho da carta do padre António Blázquez. De acordo com ele, um índio disse ao padre Gaspar Lourenço: "Siéntate i ensénhame agora mui bien, porque mi voluntad es que me bap[t]izes". Continua Blázquez: "El Padre lo ensenhó i provocó a tener contrición de sus pecados, confesándolo en la lengoa brazílica que me parese saber mejor que la portuguesa" (António Blázquez, "Carta ao padre Diego Laynes, Roma. Da Bahia, 1/9/1561", apud LEITE, 1954-1958, v. III, p. 403). Como o índio ainda não era batizado, não poderia haver confissão no sentido estrito do termo (por isso Polanco, secretário da Companhia, riscou a frase no manuscrito, como informa LEITE, 1954-1958, vol. III p. 403 nota 13). Todavia, essa prática não anula, em nosso entender, o que temos afirmado; qualquer que tenha sido o uso da confissão nesse momento da missionação (e especialmente se foi um uso "não-sacramental", como neste caso), não é suficiente para que o tomemos como eixo principal da atividade jesuítica. Mesmo no caso mencionado, é preciso destacar, a confissão encontra-se num contexto de ensino. Aliás, essa confissão anterior ao batismo é explicada pelo padre Leonardo do Vale, em carta a Diego Laínez: "...nos mandou o Padre à Igreja, os que sabiamos a lingua, a confessar os que se avião de bautisar ao outro dia. A qual confissão, como já saberão, não hé mais que pera lhe fazer detestar a vida passada e conhecerem a que querem tomar" (Leonardo do Vale, "Carta ao padre Diego Laynez, Roma. Por comissão do padre Luís da Grã. Da Bahia, 23/9/1561", apud LEITE, 1954-1958, v. III, p. 444). Nesse sentido, penso que declarações como a de Cristina Pompa, de que no trabalho dos jesuítas "prevaleceu a indicação de antepor o sacramento da confissão ao do batismo" (POMPA, 2003, p. 389; seu contexto é o das missões volantes no sertão, em fins do século XVII), merecem alguma relativização; é preciso levar em conta o contexto específico e não confundir essa confissão não-sacramental com a prática sacramental regular. Discutindo o lugar da confissão no âmbito da catequese moderna, Agnolin recorda-nos de que a confissão sacramental é sempre pós-batismal, visto ser entendida como "segunda tábua" de que o cristão pode se socorrer após o naufrágio no pecado; a "primeira tábua" é justamente o sacramento do batismo. Ver Agnolin (2007, p. 179-184); Agnolin (2007, p. 99-107), onde se trata diretamente da confissão ministrada aos indígenas e onde Agnolin sublinha, a partir do Diálogo da Fé de Anchieta, que a confissão é especificamente "remédio" que se oferece "depois do batismo, enquanto instrumento ao qual pode-se recorrer ritualmente todas as vezes que se tenha 'transgredido a lei de Deus'" (p. 100, grifos meus). É preciso cuidado, ainda, para que a confissão sacramental não seja confundida com a prática, integrante do rito batismal de adultos, de se "renunciar a Satã", também mencionada eventualmente como "confissão" (ver RAFAEL, 1988, p. 95). Estas observações não visam negar a importância que o sacramento da confissão passou a ter na conformação doutrinal católica pós-tridentina: nem seu papel basilar para os restantes sacramentos (ver RAFAEL, 1988, p. 94), tampouco, sua centralidade no "encontro sacramental' ritual" característico da conversão "indígena-tupi". Para maiores detalhamentos, ver ainda Agnolin (2007, p. 304-21) (p. 320 para as expressões citadas).

28 Manuel da Nóbrega, "Carta ao Dr. Martín de Azpilcueta Navarro, Coimbra. De Salvador, 10/8/1549". A citação latina reporta-se a Gênesis 3, 5 e diz: "Sereis, portanto, como Deus conhecedores do bem e do mal". Provavelmente feita de memória pelo autor, a citação altera apenas ligeiramente o texto da Vulgata, que diz, na parte final do versículo: "eritis sicut dii scientes bonum et malum".

29 Trata-se de tradução de De pueris statim ac liberaliter instituendis ("Sobre os meninos e a educação liberal que se deve dar logo a eles"). Infelizmente não tivemos acesso ao texto latino dessa obra de Erasmo.

30 No Enchiridion, Erasmo afirmava que "o pecado desfigurou o que estava bem realizado, tendo semeado o 
vírus da discórdia nos que se entendiam bem. Pois antes do pecado tanto a mente imperava sobre o corpo sem esforço quanto o corpo obedecia à mente com prazer e de bom grado. Agora, ao contrário, perturbada a ordem das coisas, os afetos do corpo se antepõem à razão, que se vê obrigada a seguir as determinações do corpo" ("sed peccatum quod bene conditum erat male deprauauit inter bene concordes dissensionis uirus serens. Antea enim et mens corpori sine negotio imperabat, et corpus animo lubens uolensque parebat; nunc contra perturbato rerum ordine affectus corporis rationi praeire certant, cogiturque illa in corporis sententiam pedibus discedere". (ERASMO, 1563, p. E5-E5v).

31 Pero Correia, "Carta ao padre João Nunes Barreto, África. De S. Vicente, 20/6/1551".

32 Leonardo Nunes, "Carta aos padres e irmãos de Coimbra. De S. Vicente, 20/6/1551".

33 António Pires, "Carta aos padres e irmãos de Coimbra. De Pernambuco, 2/8/1551".

34 Manuel da Nóbrega, "Carta ao rei D. João III de Portugal. Da Bahia, princípios de julho de 1552".

35 Manuel da Nóbrega, "Carta ao padre Simão Rodrigues, Lisboa. De Pernambuco, 11/8/1551".

36 Manuel da Nóbrega, "Carta ao rei D. João III de Portugal. De S. Vicente ou Piratininga, outubro de 1553".

37 Manuel da Nóbrega, "Carta ao padre Miguel de Torres, Lisboa. Da Bahia, 8/5/1558".

38 Manuel da Nóbrega, "Carta ao rei D. João III de Portugal. Da Bahia, princípios de julho de 1552".

39 Pero Correia, "Carta ao padre Simão Rodrigues, Lisboa. De S. Vicente, 10/3/1553". Neste fragmento e no anteriormente citado fica claro, em nossa opinião, como os jesuítas relacionavam a suposta "inconstância" dos indígenas e a consequente dificuldade em fazê-los cristãos com a ausência de um "rei".

40 João de Azpilcueta, "Carta aos padres e irmãos de Coimbra. Da Bahia, 28/3/1550".

41 José de Anchieta, "Carta ao padre Inácio de Loyola, Roma. De Piratininga, 1/9/1554".

42 José de Anchieta, "Carta ao padre Inácio de Loyola, Roma. De S. Vicente, fim de março de 1555" (cito a partir da tradução de Leite para o texto latino).

43 Pero Correia, "Carta ao padre Brás Lourenço, Espírito Santo. De S. Vicente, 18/7/1554". Para a prática da Igreja nos primeiros séculos, de admitir somente os batizados à liturgia eucarística, despedindo os catecúmenos após a pregação, ver Hamman (1997, p. 181-182).

44 José de Anchieta, "Carta ao padre Inácio de Loyola, Roma. De Piratininga, 1/9/1554".

45 João de Melo, "Carta ao padre Gonçalo Vaz de Melo, Lisboa. Da Bahia, 13/9/1560".

46 Ver, novamente para o contexto das comunidades cristãs no segundo século, Hamman (1997, p. 187-94). Há que ter-se em mente o quanto o "novo" ou "moderno" que recupera o "antigo" é uma característica estrutural do humanismo retórico desde Petrarca. Ver acima, bibliografia na nota 4.

47 Nesse sentido, vale a pena observar que humanistas que ecoaram fortemente o ideário erasmiano, como foi o caso de João de Barros e Damião de Góis, sentiam-se à vontade para discordar dele em aspectos que consideravam importantes para a monarquia portuguesa. Enquanto o posicionamento de Erasmo diante do uso das redes comerciais para a difusão do evangelho era algo ambíguo, mas atravessado por uma marcada desconfiança, em Damião de Góis vamos encontrar uma defesa desse comércio, baseada em uma aceitação plena da lógica que dava sustentação a essas atividades; e a dependência de uma justificativa de ordem maior, como a missionação, era parte integrante dessa lógica (GÓIS, 1945, p. 86, 88; para os posicionamentos de Erasmo, ver acima, nota 14; RODRIGUES, 2012, p. 172-176 e p. 491). João de Barros aproximou-se muito dessa suspeita erasmiana em relação ao comércio (ver BARROS, 1988, p. 174-175 [Livro V]), mas, de forma igualmente ambígua, não deixou de celebrá-lo como modo efetivo para o estabelecimento da comunicação necessária à propagação da fé (BARROS, 1988, p. 14 [Livro I, capítulo ii] e p. 102-107 [Livro III, capítulo ix]). Para a condescendência do erasmiano João de Barros em relação ao uso da violência contra os "bárbaros", "legítimo até que se estabeleça a comunicação, isto é, a evangelização e (ou) o comércio", ver Horta (1995, p. 697-702) (citação à p. 701).

48 Para as primeiras providências de Mem de Sá quanto aos aldeamentos, cf. Leite (1954-1958, v. II, p. 439); para um exemplo de sua prática, cf. Leite (1954-1958, v. III, p. 138); para seus resultados na avaliação do padre Rui Pereira, cf. Leite (1954-1958, v. III, p. 292-303).

49 Pero Correia, "Carta ao padre Simão Rodrigues, Lisboa, 10/3/1553".

50 Sobre Constantino, ver Bataillon (1996, p. 522-529, 804) (para a execução de Constantino pela Inquisição, em efígie, por suspeita de "luteranismo", no ano de 1560), p. 826-827.

51 Ver Leite (1954-1958, v. I, p. 44) ("Introdução Geral") para informações sobre Pero Correia, e notas nas p. 441 442 para detalhes sobre as edições. 
Rui Luis RODRIGUES. Doutor em História Social pela Universidade de São Paulo e professor de História Moderna no Instituto de Filosofia e Ciências Humanas da Universidade Estadual de Campinas (IFCH/UNICAMP).

Recebido em: 06/07/2017

Aprovado em: 16/10/2017 